IZA DP No. 5559

The Spread of Anti-Trafficking Policies:

Evidence from a New Index

Seo-Young Cho

Axel Dreher

Eric Neumayer

March 2011 


\title{
The Spread of Anti-Trafficking Policies: Evidence from a New Index
}

\author{
Seo-Young Cho
}

University of Goettingen

Axel Dreher

University of Heidelberg, University of Goettingen, CESifo, KOF Swiss Economic Institute and IZA

Eric Neumayer

London School of Economics

\author{
Discussion Paper No. 5559 \\ March 2011
}

\author{
IZA \\ P.O. Box 7240 \\ 53072 Bonn \\ Germany \\ Phone: +49-228-3894-0 \\ Fax: +49-228-3894-180 \\ E-mail: iza@iza.org
}

\begin{abstract}
Any opinions expressed here are those of the author(s) and not those of IZA. Research published in this series may include views on policy, but the institute itself takes no institutional policy positions.

The Institute for the Study of Labor (IZA) in Bonn is a local and virtual international research center and a place of communication between science, politics and business. IZA is an independent nonprofit organization supported by Deutsche Post Foundation. The center is associated with the University of Bonn and offers a stimulating research environment through its international network, workshops and conferences, data service, project support, research visits and doctoral program. IZA engages in (i) original and internationally competitive research in all fields of labor economics, (ii) development of policy concepts, and (iii) dissemination of research results and concepts to the interested public.
\end{abstract}

IZA Discussion Papers often represent preliminary work and are circulated to encourage discussion. Citation of such a paper should account for its provisional character. A revised version may be available directly from the author. 


\section{ABSTRACT}

\section{The Spread of Anti-Trafficking Policies: Evidence from a New Index}

We analyze the spread of policies dealing with international trafficking in human beings. Arguing that countries are unlikely to make independent choices, we identify pressure, externalities and learning or emulation as plausible diffusion mechanisms for spatial dependence in anti-trafficking policies. We develop a new index measuring governments' overall anti-trafficking policies for 177 countries over the 2000-2009 period. We also assess a country's level of compliance in the three main constituent dimensions of anti-trafficking policies - prosecution, protection and prevention. Employing a spatial autoregressive model, we find that, with the exception of victim protection measures, anti-trafficking policies diffuse across contiguous countries and main trading partners due to externality effects. We find evidence for learning or emulation effects in all policy domains, with countries looking toward peers with similar political views or cultural values. Surprisingly, major destination countries do not seem to exert pressure on relevant main countries of origin or transit to ratchet up their policies.

\section{NON-TECHNICAL SUMMARY}

According to the U.S. Department of State, there are more than 12 million victims of human trafficking worldwide. We investigate the spread of governments' anti-trafficking policies around the world, using a new index. Our results suggest that anti-trafficking policies mainly diffuse across contiguous countries and main trading partners due to externality effects and via political and cultural similarities due to learning and emulation.

JEL Classification: $\quad$ O15, F22, P41

Keywords: $\quad$ human trafficking, human rights, spatial dependence of policies

Corresponding author:

Axel Dreher

University of Heidelberg

Alfred-Weber Institute for Economics

Bergheimer Strasse 58

D-69115 Heidelberg

Germany

E-mail: mail@axel-dreher.de

\footnotetext{
* We thank Nina Breitenstein, Laura Felfeli, Ulrike Heyken, Veronika Kling, Marleen Knipping, Tabea Lakeman and Lukas Semmler for excellent research assistance, Scott Jobson for excellent proofreading and Krishna Vadlamannati and seminar participants at the University of Goettingen for excellent comments. The authors cordially acknowledge the generous funding provided by the European Commission (JLS/2009/ISEC/AG/005).
} 


\section{Introduction}

In the last few decades, human trafficking has become a growing phenomenon worldwide. The illicit trade in human beings across borders violates the human rights of victims, threatens national security and deteriorates the health of the affected economies and societies by increasing the size of the shadow economy and organized criminal activities (Belser 2005). Although the exact magnitudes and dimensions of the problem are unknown, available statistics suggest that human trafficking is one of the most serious transnational crimes in the $21^{\text {st }}$ century. According to the U.S. Department of State (2010), there are more than 12 million victims of human trafficking worldwide. Interpol (2009) estimates that human trafficking is a multi-billion-dollar business, amounting to the third largest transnational crime following drug and arms trafficking.

Human trafficking can be seen as one of the dark sides of globalization. As advancements in technology and transportation connect countries more closely regardless of geographical distances, illicit flows of human beings have also become a global phenomenon. Anecdotal evidence suggests that traffickers recruit victims worldwide and transfer them from one country to another, often across continents (U.S. Department of State 2010). For instance, according to the UNODC (2006), trafficking victims found in the United States came from 66 countries in different regions (China, Mexico and Nigeria for example). Germany, another major destination, receives trafficking victims from at least 51 countries, including many from outside Europe (Afghanistan, Colombia, the Dominican Republic, etc.).

Given the growing significance of international human trafficking, it is no surprise that the international community has adopted several measures in the past ten years, including the United Nations Convention against Transnational Organized Crime and its Protocol to Prevent, Suppress and Punish Trafficking in Persons, especially Women and Children (2000, hereinafter the "Convention" or "Protocol”). Accordingly, social scientists have started to turn their attention towards policies enacted to combat human trafficking (Akee et al. 2010; Auriol and Mesnard 2010; Avdeyeva 2010; Bartilow 2010; Cho and Vadlamannati 2011; Di Tommaso et al. 2009; Friebel and Guriev 2006; Mahmouda and Trebesch 2009; Simmons and Lloyd 2010). One of the problems scholars face is the lack of reliable data on countries' antitrafficking policies which can be compared over time and between countries. The U.S. Department of State reports a ranking of countries with respect to their actions in fighting human trafficking. They use a scale of $1-3,{ }^{1}$ which is based on the level of compliance with

\footnotetext{
${ }^{1}$ The tier-ranking consists of tier 1, 2, 2-watchlist and 3. "Tier 2" and "tier 2-watchlist” reflect the same level of compliance (with 'watchlist' providing information about a country's development relative to the previous year).
} 
the United States 2000 Victims of Trafficking and Violence Protection Act (TVPA). However, the tier ranking has several drawbacks, which limit its reliability and relevance. ${ }^{2}$ In particular, while the tier ranking provides an aggregate score of compliance with anti-trafficking policies, it fails to recognize the different levels of compliance in the three main policy dimensions prosecution, protection and prevention. Separating the three dimensions is important. Theory and evidence indicate that better protection policy may encourage potential victims to risk illegal migration, which could lead them to fall prey to traffickers. Human trafficking inflows might therefore increase as a consequence, contradicting the objectives of prosecution and prevention policies (Akee et al. 2010). Countries can thus have the same overall ranking on the index, but for very different reasons. ${ }^{3}$

We make two important contributions to the growing literature on human trafficking. First, we develop novel and original indices of anti-trafficking policies around the world, providing better, more detailed and disaggregated measures of the three prime policy dimensions enacted by countries. Specifically, we use raw data from two reports on human trafficking - the Annual Reports of Trafficking in Persons (United States State Department, 2001-2010) and the Reports on Trafficking in Persons: Global Patterns (United Nations Office on Drugs and Crime, 2006 and 2009) - to construct separate indices on the three policy dimensions (prosecution, protection and prevention), as well as one overall aggregate antitrafficking policy index for up to 177 countries over the 2000-2009 period. The index provides a score from 1 to 5 for the level of compliance, with each dimension of antitrafficking policies for each country and year. Second, we argue that policy choices across countries are very unlikely to be independent from each other. Major destination countries will wish to push for policy changes in relevant transit and origin countries. More generally, international human trafficking creates significant cross-country externalities and countries will also want to learn from or emulate the policies enacted by other countries. Because of these cross-country spillover effects, we argue that countries spatially depend on each other in

\footnotetext{
${ }^{2}$ The decision rule of the tier-ranking is not transparent to the public. It is not clear how the three levels of the ranking - full compliance, significant efforts and no significant efforts - are assessed and determined, making the ranking vulnerable to subjectivity (GAO 2006). It has been argued the tier-ranking is largely a tool of the U.S. government to influence other country's policies through 'naming' and 'shaming' (Simmons and Lloyd 2010). It is determined based on evaluation of compliance with the United States' domestic anti-trafficking law - the Victims of Trafficking and Violence Protection Act (TVPA 2000) - rather than international law. Its relevance for evaluating international standards is therefore limited.

${ }^{3}$ A number of countries in full compliance with the tier-ranking fail to ensure the basic legal rights of victims, punishing and deporting them, while demonstrating sound policy interventions in the other dimensions (prosecution and prevention). For instance, in the tier 1 group, victims in France and the United Kingdom were reportedly imprisoned and deported due to their actions related to the situations in which they were trafficked in 2008 and 2009 (U.S. Department of State, 2009 and 2010).
} 
their respective policy choices. We empirically investigate this hypothesis with a spatial autoregressive estimation model.

To foreshadow our results, we find evidence for spatial dependence in anti-trafficking policies. In particular, policies diffuse via externality effects across contiguous countries and main trading partners - with the exception of protection policies, for which one would not expect any externality effect. Policies also diffuse via learning or emulation effects as countries look for cues (or information) from other countries sharing political and cultural similarities. However, we do not find any significant effect of pressure from the United States via aid. Nor do we find evidence that major destination countries pressurize relevant major transit and origin countries to enact stricter anti-trafficking policies.

We proceed as follows. In section 2, we develop theoretical arguments as to why antitrafficking policies are not independently chosen by countries. In section 3, we introduce our indices on anti-trafficking policies. The method of estimation and data are described in section 4, while we discuss our results in section 5. Section 6 tests for the robustness of our results. The final section concludes the paper.

\section{Spatial Dependence in Anti-trafficking Policies}

Spatial dependence in policy choices has become a key concept in the recent literature analyzing policy diffusion across countries (Neumayer and Plümper 2010; Gassebner et al. 2011; Gauri 2011; de Soysa and Vadlamannati 2010; Greenhill et al. 2009; Eichengreen and Leblang 2008; Pitlik 2007; Blonigen et al. 2007). Spatial dependence exists whenever the marginal utility of one unit of observation (here: a country) is affected by the decision-making of other units of observation (Neumayer and Plümper 2010). For example, if policies enacted in one country are influenced by policy choices in other countries, then they are said to spatially depend on each other. From a theoretical perspective, spatial dependence can result from pressure, externalities, learning and emulation (Elkins and Simmons 2005; Simmons and Elkins, 2004). ${ }^{4}$ The major destination countries of internationally trafficked persons are likely to exert pressure onto countries which function as major sources of transit and/or origin for people trafficked into these major destinations. Major destination countries will be averse to illegal migration into their territories (as international trafficking always is) and will resent the increase in other transnational criminal activities (such as drug and arms trafficking) that typically accompany human trafficking (Bartilow 2010). Moreover, human trafficking creates

\footnotetext{
${ }^{4}$ They list coercion, rather than pressure, and add competition. However, coercion is incompatible with policy choice and competition can be subsumed under externalities. On the other hand, emulation could be subsumed under learning unless countries blindly follow others in their policy choices.
} 
a shadow economy of illegal labor markets and businesses with estimated annual profits of some one billion dollars in industrialized countries (Belser 2005) - money which is not taxed and is likely to be used for illegal activities. Yet, the effectiveness of policies undertaken in destination countries will be undermined if other countries, particularly relevant transit and origin countries, do not follow suit. The strictest anti-trafficking policies in destination countries may be ineffective if countries of origin and transit have lax policies in place. Hence, successful anti-trafficking policies in destination countries depend on a ratcheting up of policies in origin and transit countries, as well as major destination countries exerting pressure on laggards.

In addition to pressure, externalities are rampant in this policy area (Simmons and Llyod 2010). Anti-trafficking policies enacted by one country create significant externalities that other countries cannot simply ignore. Stricter policies in one destination country will deflect some of the flows of trafficked persons into other destination countries, while stricter policies in one origin or transit country will prompt transnational trafficking networks to increasingly resort to other origin or transit countries. Similar to international drug-trafficking, unless policies can address the underlying supply and demand factors driving international trafficking (which they typically cannot), stricter anti-trafficking policies in one country will merely deflect the problem onto other countries with weaker policies in place, such that there is an incentive to ratchet policies upwards over time. In other words, by predicting externality effects of such transnational crime, countries will be able to update their anti-trafficking measures, following relevant policy changes of other countries which share certain characteristics, such as geographic proximity and economic similarity.

Lastly, anti-trafficking policies are being set in a relatively new arena of public policies, with some countries, such as the United States and a few countries in Western Europe, running ahead of others. Laggards will be uncertain in regards to which policies to choose on their own, and will therefore look for cues (or information) in the policies of other countries. Importantly, countries will not simply wish to follow the top leaders in North America and Western Europe. These are all major destination countries and following their lead may not produce positive outcomes in other countries - mostly origin and transit countries of trafficking victims - because the root causes of the problem and the groups targeted differ from those of the leading countries as does their cultural and political setting. In dealing with uncertainty regarding policy design and its outcomes, the more competently governed lagging countries will want to actively learn from leaders in their reference groups i.e., from culturally, politically, or geographically proximate countries who are also early 
adopters of relevant policies (Elkins and Simmons 2005), while other laggards may simply wish to emulate or mimic policies from other reference countries without any major learning effect.

In sum, there are many reasons why one would expect spatial dependence in antitrafficking policies. Some countries will be pressured by others, some will experience externalities created by others, and some will want to learn from or emulate others. Importantly, the strength of these effects will differ across countries, depending on how and to whom they are connected. To test for these hypothesized spatial dependence effects, we estimate spatial autoregressive models in section 5, in which the spatially-weighted policy choices of other countries are allowed to affect the domestic policy choice of the country under observation, with the weights capturing the various types of connectivity among countries. Before discussing our empirical research design, we explain how we have coded novel measures of anti-trafficking policies.

\section{Novel Measures of Anti-trafficking Policies}

In response to the emergence of human trafficking onto the international policy arena, several important international legal instruments have been introduced in the past ten years, including the United Nations Convention against Transnational Organized Crime and its Protocol to Prevent, Suppress and Punish Trafficking in Persons, especially Women and Children (2000) and the Council of Europe Convention on Action against Trafficking in Human Beings (2008). ${ }^{5}$ The adoption of the Convention and the Protocol is followed by rapid ratification by countries. After opening for signature in November 2000, the Convention has been ratified by 158 parties and the Protocol by 142 to date. The Protocol in particular represents an important step forward, by providing an internationally recognized definition of human trafficking ${ }^{6}$ for the first time, as well as introducing its three important policy dimensions: (i) prosecuting

\footnotetext{
${ }^{5}$ There are several earlier versions of international treaties for human trafficking, including the International Agreement for the Suppression of the "White Slave Traffic" (1904). Several other international treaties relevant to human trafficking exist today: The International Labor Organization Convention 182, the Elimination of Worst Forms of Child Labor (1999); the United Nations Optional Protocol to the Convention on the Rights of the Child on the Sale of Children, Child Prostitution and Child Pornography (2000); the International Labor Organization Convention 29, Forced Labor (1930); and the International Labor Organization Convention 105, Abolition of Forced Labor (1957).

${ }^{6}$ According to the Anti-trafficking Protocol, trafficking in persons shall mean the recruitment, transportation, transfer, harboring or receipt of persons, by means of the threat or use of force or other forms of coercion, of abduction, of fraud, of deception, of the abuse of power or of a position of vulnerability or of the giving or receiving of payments or benefits to achieve the consent of a person having control over another person, for the purpose of exploitation. Exploitation shall include, at a minimum, the exploitation of the prostitution of others or other forms of sexual exploitation, forced labor or service, slavery or practices similar to slavery, servitude or the removal of organs (article 3-(a)).
} 
(criminalizing) traffickers, (ii) protecting victims, and (iii) preventing the crime of human trafficking (UNODC 2006).

Our novel and original indices are coded to reflect policies in these three dimensions. We decompose each dimension into several important requirements prescribed by the Protocol and evaluate compliance for each of them. Compliance with these requirements is independently evaluated by at least two trained coders based on clearly instructed coding guidelines and decision rules. ${ }^{7}$ The scores for each dimension are aggregated to a five-point scale ranging from 1 to 5 , where the highest value indicates full compliance and the lowest value no compliance. ${ }^{8}$

The raw data are derived from two reports on human trafficking, the Annual Report of Trafficking in Persons (United States State Department, 2001-2010) and the Report on Trafficking in Persons: Global Patterns (United Nations Office on Drugs and Crime, 2006 and 2009). The U.S. State Department reports provide detailed country narratives every year on the anti-trafficking efforts of up to 180 countries in the three dimensions of human trafficking listed above (an annual report covering the period one year before publication). The UN Office on Drugs and Crime reports include information about criminal justice and victim protection policies in approximately 155 countries for various years. ${ }^{9}$ As the State Department's reports provide systematic and comprehensive information covering a larger number of countries each year, we use these as our main source. We then check the validity of the information provided by employing the UN reports.

The sub-index on 'prosecution policy' measures the level of governments' efforts to punish and prosecute traffickers and other related offenders (such as employers of trafficking victims, law enforcement officials who collude with traffickers, and clients of services provided by human trafficking victims). The prime requirements for governments to implement are broken down into six areas: (i) the adoption of anti-trafficking law, (ii) the adoption of child trafficking law, (iii) the application of other relevant laws, (iv) the stringency of penalties, (v) the level of law enforcement, and (vi) the collection of crime statistics. We select these requirements based on article 5 (criminalization) of the Protocol. Countries receive the highest possible score (five) if the country has a legislative measure specifically prohibiting trafficking in persons and the law is fully enforced. It receives a score of four if it has adopted legislative measures specifically prohibiting trafficking in persons but

\footnotetext{
${ }^{7}$ Appendix 1 presents a short version of the coding guidelines. The full version is available in our online appendix (www.human-trafficking-research.org).

${ }^{8}$ In the rare case of disagreement between the two coders, the principal investigators decided on the scores.

${ }^{9}$ The reports summarize information about the adoption and implementation of anti-trafficking policies from the 1990s to the present, but do not provide systematic information on an annual basis.
} 
the law is not fully enforced. A score of three is coded if the country does not have a legislative measure specifically prohibiting trafficking in persons but applies some other relevant laws to punish offenders and this other law is at least adequately enforced. A score of two implies that the country does not have a legislative measure specifically prohibiting trafficking in persons, but it applies some other related law to punish offenders without, however, adequately enforcing this law. If the country has a legislative measure specifically prohibiting trafficking in persons but does not enforce the law at all it also receives a score of two. The lowest possible score of one is obtained if the country does not have a legislative measure prohibiting trafficking in persons, no other law is applied, and there is no evidence of punishment for such a crime at all. The short description of the coding guideline is reproduced in Appendix A and the detailed full version is available in our online appendix. ${ }^{10}$

The second sub-index, 'protection policy', is coded analogously. It assesses the level of governmental efforts to protect and assist the victims of human trafficking. Nine prime requirements imposed by the Protocol (article 6, 7 and 8) are evaluated: (i) no punishment of victims, (ii) imposing no self-identification in order to prove their status as a victim; (iii) assistance for legal proceedings, (iv) the provision of residence permits, (v) basic services for housing, (vi) medical training, (vii) job training, (viii) assistance for rehabilitation and (vi) assistance for repatriation. Ensuring no punishment of victims receives special consideration in our evaluation ${ }^{11}$ because this requirement represents a basic human right in anti-trafficking policy, recognizing 'victims of exploitation’ (UNODC 2006; Cameron and Newman 2008: Chapter 1). The highest score of five is given to countries demonstrating very strong efforts in preventing trafficking in persons. Countries obtain a score of four (three) if they demonstrate strong (modest) efforts against trafficking in persons, and a score of two for limited efforts. A score of one is given if the country demonstrates no effort against trafficking in persons. Again, the coding guidelines are provided in Appendix A and the online appendix.

The third dimension of anti-trafficking policies, 'prevention policy', evaluates the level of governmental efforts to prevent and combat human trafficking. Based on the requirements of the Protocol provided in article 9, 10, 11, 12 and 13, seven areas are evaluated. Examples are the implementation of campaigns for anti-trafficking awareness; training government and military officials (including peace keepers); facilitating information exchange among relevant authorities; monitoring borders, train stations, airports, etc.; adopting national action plans for combating trafficking in persons; promoting cooperation

\footnotetext{
${ }^{10}$ See www.human-trafficking-research.org.

${ }^{11}$ To obtain score 4 or 5 , the requirement of no punishment of victims has to be satisfied.
} 
with NGOs and international organizations; and facilitating cooperation with other governments. Again, the index ranges between one and five, with higher values reflecting stricter policies, as detailed in Appendix A.

In addition to the three sub-indices, we also calculate an overall " $3 \mathrm{P}$ ” anti-trafficking policy index. This is computed as the unweighted sum of the three dimensions. The overall index thus ranges between 3 and 15. It is available for up to 175 countries over the 2000-2009 period. Data availability and global and regional average scores are illustrated for selected years in Table 1. As can be seen, relevant information becomes available for more countries over time. As expected, the developed world performs better than the rest of the world. European and OECD countries demonstrate the highest commitments to anti-trafficking policies in all of the three dimensions, while efforts are minimal and even decreasing in South Asia and the Middle East in recent years.

Table 1 is based on all available information with changing country samples over time. In order to detect policy changes over time, we prefer to fix the sample to those countries that have data available over the entire period of time. This is done in figures 1-3, which illustrate how anti-trafficking policies in different groups of countries develop over time. This graphical illustration shows that the level of compliance in all of the three dimensions improved for the last ten years (see figure 1). In particular, compliance with prosecution policy was highest, on average, for all years and experienced the most significant improvement during the period: In the fixed sample, the worldwide average score of 2.90 in 2000 increased to 4.26 in 2009 . Meanwhile, the average prevention policy score increased from 2.53 in 2000 to 3.67 in 2009. On the contrary, our index suggests that governmental efforts to protect victims of human trafficking remain weaker than their efforts to criminalize traffickers and prevent the crime of human trafficking. The worldwide average score of protection policy are lowest for all years, e.g., 2.26 in 2000 and 2.97 in 2009, and also shows the slowest improvement over time. This descriptive outcome of our index indicates that, in terms of compliance with anti-trafficking policy, countries take the ‘justice and prevention' aspect of the crime more seriously than the human rights aspect, as pointed out by Simmons and Lloyd (2010).

Figure 2 shows the development of the $3 \mathrm{P}$ index across regions over time, while figure 3 contains the same information for different income groups. As can be seen, with the exception of the Middle East/North Africa and South Asia, there are clear improvements in compliance with anti-trafficking policies over time. It is in these regions, together with SubSaharan Africa, where the overall level of the anti-trafficking policy index is lowest in 2009. It is also remarkable that the $3 \mathrm{P}$ index showed high values in the Western Europe and other 
industrialized countries group, while the remaining groups converged to this higher level over the 2000-2009 period. Splitting the sample up by income, the index levels are particularly high for OECD countries. High-income non-OECD countries show lower levels of compliance with anti-trafficking policies, comparable to those of low income countries, as well as lower and upper middle income countries. All country groups have improved their index values since 2000 .

Table 2 shows that the three dimensions of the 3P anti-trafficking policy index are clearly not redundant. It reports the correlation coefficients across the sub-indices and the overall index, as well as the U.S. Department of State's tier-ranking. Not surprisingly, the three dimensions are positively correlated with each other. However, the correlations among the sub-indices of the $3 \mathrm{P}$ index are modest, ranging between 0.52 and 0.64 . This suggests that the sub-indices are individually relevant and the disaggregation into the three dimensions captures differences in compliance across countries with each of the 3Ps. ${ }^{12}$ The table also shows the modest levels of correlation between each of the 3Ps and the tier-ranking. The correlation of 0.72 between the aggregate $3 \mathrm{P}$ index and the tier-ranking suggests that both measures capture the general direction of the development of anti-trafficking policies, but are to some extent different. We stress that compared to the tier-ranking, our index does not rely on a single informational source, but integrates all available information in order to minimize potential biases one informational source may have.

\section{Estimation Model, Method and Data}

Our baseline estimation model follows the specification in Bartilow (2010). His dependent variable is the level of compliance with the United States 2000 Victims of Trafficking and Violence Protection Act (TVPA). The U.S. Department of State reports a ranking of countries with respect to their actions to fight human trafficking, on a scale of $1-3 .{ }^{13}$ On the original scale, countries whose governments fully comply with the TVPA receive the lowest value (tier 1). Countries with governments not fully complying with the minimum standards required but exerting a significant effort to achieve full compliance, are ranked medium (tier 2), while countries with governments that do not fully comply and do not exert significant efforts are ranked highest (tier 3$).{ }^{14}$ We recode the ranking so that higher values are deemed

\footnotetext{
${ }^{12}$ The usual threshold for regarding sub-dimensions as relevant is a correlation of at most 0.7 (McGillivray and White 1993).

${ }^{13}$ Bartilow (2010) uses a fourth category relying on information on how a country’s policies evolve compared to the previous year (i.e., whether the country is on the "watchlist"). We do not follow this coding, as "tier 2" and "tier 2-watchlist" reflect the same level of compliance.

${ }^{14}$ See the Trafficking in Persons Report (2010), U.S. Department of State.
} 
"better.” We use this dependent variable only in a baseline regression for comparative reasons. Our main estimations are based on our newly constructed anti-trafficking policy variables.

Our regressions are based on pooled time-series cross-section (panel) data, covering the 2002-2009 period. ${ }^{15}$ We use robust standard errors, clustered at the country level, to account for the fact that observations from the same country in different years are not independent observations. Since some of the data are not available for all countries or years, the panel data are unbalanced and the number of observations depends on the choice of explanatory variables. Still following Bartilow, we include the temporal lag of the dependent variable, which turns out to be highly significant according to all specifications. Our preferred estimation equation takes the following form:

$$
y_{i, t}=\alpha+\beta_{1} y_{i, t-1}+\beta_{2}^{\prime} X_{i, t}+\beta_{3} \sum_{k} \omega_{i k t-1} y_{k t-1}+\eta_{i}+\lambda_{t}+\varepsilon_{i, t},
$$

where $y_{i, t}$ represents our measures of anti-trafficking policies in country $i$ at year $t, X_{i, t}$ is the vector of explanatory variables, $\eta_{i}$ and $\lambda_{t}$ represent country and year fixed effects respectively, and $\varepsilon_{i, t}$ represents the idiosyncratic error term. The spatial lag variable $\sum_{k} \omega_{i k t-1} y_{k t-1}$ consists of the product of the 'spatial y' and a spatial weighting matrix $\omega_{i k t-1}$. The spatial y is the value of the dependent variable in other countries $k$, while the spatial weighting matrix measures the relative connectivity between country $i$ and other countries $k$ (Plümper and Neumayer 2010). We use different weights, as explained below, thus generating different spatial lag variables, which enter separately in the estimation models. The reason for not including them together in our preferred specifications is that the spatial lag variables are highly correlated with each other, thus creating multi-collinearity problems if jointly estimated. $^{16}$ Still, we also report results with all spatial lag variables included. We rowstandardize all weighting matrices, such that the spatial lag variables represent the weighted average of policies in other countries. This practice, which is typically, if erroneously, regarded as standard practice (Plümper and Neumayer 2010), is nevertheless justified here. Our theory predicts that countries will learn from their civilizational peers and main trading partners, independent of how many peers there are or how much they absolutely trade. With this is mind, row-standardization is appropriate. All spatial lag variables are temporally

\footnotetext{
${ }^{15}$ Data on compliance with human trafficking policies for the years 2000-01 are also available. However, given that values are missing for many countries in these years we exclude them from the analysis.

${ }^{16}$ In our estimation sample, the correlation of the spatial lags is around 0.5. Note that the significant coefficients might thus to some extent reflect the effects of other, omitted, lags.
} 
lagged by one year since it is unlikely that countries could react to the policies of other countries immediately (i.e., in the same year).

The dependent variables are categorical and ordinal, for which in principle ordered probit or ordered logit would be the most appropriate estimators. However, the larger the number of categories, the less persuasive the case for using ordered probit or logit (Wooldridge 2002) and our aggregate 3P index has 15 categories. Moreover, Hausman tests strongly call for the inclusion of country fixed effects to avoid omitted variable bias from unobserved country heterogeneity (see equation (1)), which is facilitated by using a linear estimator like ordinary least squares (OLS) or the system GMM estimator suggested by Arellano and Bover (1995) and Blundell and Bond (1998). We therefore use both ordered probit, OLS and system GMM.

In choosing our control variables, we follow Bartilow (2010) and include an index of control of corruption. This perceptions-based index is provided by Kaufmann et al. (2009) and ranges from -1.63 (high risk of corruption) to 2.58 (low risk of corruption), in the estimation sample of Table 3, column 1 below. ${ }^{17}$ As Bartilow argues, enforcement of policies is likely to depend on the government and bureaucracy's capacity to enforce these policies. With rising corruption, both bureaucrats and government officials are less likely to enforce sound policies. A lower degree of corruption is thus likely to improve policies against human trafficking. We include the Polity IV indicator of democracy, ranging between -10 and 10, with higher values representing a more democratic political regime (Marshall and Jaggers 2009). This is because democratic governments should be more likely to follow international law (Bjørnskov 2010, Dixon 1993, Hathaway 2007, Neumayer 2005, Slaughter 1995). In democratic countries, it is easier for citizens, non-governmental organizations and the media to monitor governmental compliance with an international treaty. Furthermore, as the democratic legalism literature suggests, democracies are more likely to comply with international legal obligations because of their respect for judicial processes and constitutional constraints carried over into the realm of international politics (Simmons 1998). According to Bartilow, gender representation is important for human trafficking policies. As he argues, women are more likely to pursue policies which protect their own rights. ${ }^{18}$ We measure the level of women's rights employing two indicators: The percentage of female parliamentarians in the national parliament (taken

\footnotetext{
${ }^{17}$ Bartilow uses Transparency International's Corruption Perception Index. However, this index does not provide comparable time-series data and substantially reduces the number of observations if included, so we prefer to use the index provided by Kaufmann et al. (2009) here.

${ }^{18}$ This is in line with the broader literature. For example, according to Chattopadhyay and Duflo (2005), reservation of political mandates for women in India has led to policies benefiting especially women. Studying voting behavior of U.S. congressmen, Washington (2006) finds that congressmen with daughters are substantially more likely to vote in-line with feminist views.
} 
from the World Bank Gender Statistics 2010) and the Cingranelli-Richards indicator of women's economic rights. ${ }^{19}$ We code an International Regime dummy variable, using data on whether or not a country has ratified the United Nations Protocol to Prevent, Suppress and Punish Trafficking in Persons, especially Women and Children (2000). Finally, we include a country's (log) per capita GDP and the amount of U.S. aid inflows (as a percentage of GDP). While per capita GDP proxies for a country's level of development, U.S. aid measures the potential pressure exerted by the U.S. to reform policies. Indeed, the U.S. State Department sometimes threatens to withhold aid in case of non-compliance with human trafficking policies (U.S. Department of State, Annual Report on Trafficking in Persons 2004). ${ }^{20}$ In section 2, we identified pressure as one of the reasons for spatial dependence in antitrafficking policies. The inclusion of the U.S. aid measure is meant to capture any pressurizing effect that the U.S. might exert on aid-receiving developing countries, such that our spatial lag variables, to which we turn now, do not simply pick up the effect that U.S. pressure has on policies in the main recipient countries of its aid.

As argued in section 2, when choosing anti-trafficking policies, countries are very likely to spatially depend on the policy choices of other countries. Such spatial dependence is best analyzed in what is called a spatial autoregressive model, in which the weighted average of the dependent variable in other countries (the so-called spatial lag variable), enters the estimation equation as an explanatory variable. The weights used in the construction of the spatial lag variable represent the relative importance of foreign countries' policy choices for domestic policy-making in the country of observation. Weights can be dichotomous, as is the case with the dummy variables for the location of countries in a certain region or the sharing of a common border between countries, or continuous, as is the case for the variables measuring the spatial proximity between countries or the importance of their trade relationship.

In section 2, we identified pressure, externalities, learning and emulation as reasons for spatial dependence in anti-trafficking policies, i.e., as causal mechanisms or channels

\footnotetext{
${ }^{19}$ Bartilow uses a narrower indicator on gender equality of marriage and divorce, while we prefer to use an indicator more broadly defined. Using the CIRI indicator of women's social rights, we lose more than 400 observations, so we prefer taking the economic rights indicator. Correlation between the two among our sample is 0.64 .

${ }^{20}$ Bartilow (2010) uses the absolute amount of U.S. aid. We prefer to scale inflows by GDP in order to avoid capturing a mere scale effect. We also included the share of women among the ministers of a country's government (taken from various issues of the UNDP Human Development Reports). Given that these data are only available for four years, we had to use linear interpolation before being able to include the variable in the regression. Note however, that the share of female ministers is not significant at conventional levels in any of the specifications shown in Table 3. Bartilow also uses some additional variables that did not turn out to be significant at conventional levels in his regressions. We do not include them here.
} 
through which policies might diffuse. Unfortunately, it is not possible to choose weights that either perfectly or exclusively capture one of these diffusion channels. However, our weights were chosen with a view to account for these channels as much as possible. Specifically, as weighting variables we use information on the identity of the major transit and source countries for each destination country, contiguity (two countries share a land border or are separated by less than 150 miles of sea distance), bilateral trade, similarity in voting on those issues regarded as key by the United States in the United Nations General Assembly, ${ }^{21}$ and a civilizational dummy. Transit and source countries are vulnerable to pressure from their major destination countries since the effectiveness of policies in the latter requires the ratcheting-up of policies in the former. Note that in the estimations containing this spatial lag variable, the sample is reduced to countries which function as major transit or origin countries as we assume that these countries experience pressure from destination countries. The relevant spatial lag variable is undefined for countries that do not fall into this category. Contiguity and bilateral trade predominantly capture externalities. A country contiguous to other countries $k$ is likely to experience the strongest impact of any externality generated by policy choices in countries $k$. This is because contiguous countries tend to be close substitutes as either destination, transit or origin countries. The same is true for countries which trade a lot with each other, not least because flows of people often follow flows of goods and services. Of course, contiguity and bilateral trade do not exclusively capture externality effects, but will also partly cover learning and emulation effects if countries learn from or emulate those countries of geographical proximity or economic importance. To some extent, due to the correlation among the spatial lags they will in part also capture the impact of the omitted lags. Yet, we argue that similarity of voting and the civilizational belonging of countries predominantly capture learning and emulation effects. Countries wishing to learn from or emulate other countries will seek those with which they share common political views and/or values. The similarity of voting in the UN General Assembly, particularly on key issues, captures the similarity of political views well, while countries belonging to the same civilization, such as the Western, Islamic, African, Latin American, Sinic or Hindu groups, are likely to share common values.

\footnotetext{
${ }^{21}$ Not all votes in the General Assembly are likely to be of great importance. Focusing on a sub-set of votes might thus be superior. The U.S. State Department provides a classification of votes it considers important in yearly reports since 1983. Arguably, these votes are also likely to be the more important ones (on average) for countries other than the United States. The voting behavior of each country on every roll call vote in the UN General Assembly since 1946 has been documented by Voeten and Merdzanovic (2008), and revised by Kilby (2009).
} 
Appendix B shows the exact definitions of all variables with their sources, while Appendix C reports descriptive statistics.

\section{Results}

Column 1 of Table 3 replicates the analysis of Bartilow (2010) for our sample and definition of explanatory variables. The dependent variable is the 3-scale tier ranking provided by the U.S. Department of State. Given the ordinal nature of the dependent variable, estimation is carried out with ordered probit. We therefore omit the country fixed effects because including country dummies in ordered probit/logit models with a limited number of observations tends to produce inconsistent estimates - the so-called incidental parameter problem (for a summary see Lancaster 2000). We do however include a dummy for each year.

As can be seen in column 1, the quality of a country's anti-trafficking policy improves with the perceived absence of corruption and a more democratic regime, at the one and five percent levels of statistical significance, respectively. At the ten percent level, better women's rights on the CIRI indicator are correlated with stricter policies against human trafficking. The lagged dependent variable is also significant at the one percent level, with the expected positive coefficient. Contrary to the results in Bartilow, per capita GDP, U.S. aid, and international regime membership are not significant at conventional levels. ${ }^{22}$

Column 2 replicates the analysis using our overall 3P index as the dependent variable instead. As can be seen, the results are largely unchanged. The exception is the control of corruption index, which turns out to be insignificant at conventional levels.

Given that our 3P index contains 15 categories, OLS seems suitable as well. Given that it also eases the quantitative interpretation of the coefficients, we report OLS results in columns 3 and 4 . While column 3 excludes country fixed effects, column 4 includes them. Excluding fixed effects, the results are almost identical to the ordered probit specification. However, once we include them, the control of corruption index is significant at the five percent level, while the share of women in the legislature is no longer significant at conventional levels. Surprisingly, the coefficient of democracy reverses its sign, but is only significant at the ten percent level.

With the temporally lagged dependent variable and the country fixed effects simultaneously included in the estimations, our results could be biased and inconsistent in a short panel (Nickell 1981). We therefore proceed with the system GMM estimator as

\footnotetext{
${ }^{22}$ Note however that Bartilow uses instrumental variables to take account of the potential endogeneity of U.S. aid. Given that this variable is not central to our analysis, we do not follow Bartilow here, but acknowledge the likely endogeneity of the variable.
} 
developed in Arellano and Bover (1995) and Blundell and Bond (1998). Results are based on the two-step estimator implemented by Roodman (2005) in Stata, including Windmeijer's (2005) finite sample correction. The Hansen test on the validity of the instruments used (amounting to a test for the exogeneity of the covariates), and the Arellano-Bond test of second order autocorrelation (which must be absent from the data in order for the estimator to be consistent), do not reject the specification at conventional levels and thus support our choice of which variables to model as exogenous.

The results from column 5 are similar to those obtained previously with ordered probit and OLS (excluding country fixed effects). In columns 6 and 7 we replicate the results excluding the three variables that are never significant at conventional levels (international regime membership, per capita GDP and U.S. aid). The results are unchanged.

Quantitatively, we find that an increase in the democracy index by one point increases the 3P index by 0.07 points, while an increase in the women's rights index by one point increases it by 0.24 points (focusing on the GMM results reported in column 7). An increase in corruption by 0.1 on the -1.6 to 2.6 scale, increases the 3P index by almost 0.04 .

In Table 4 we turn to the estimation of our hypothesis of spatial dependence in antitrafficking policies, initially focusing on the aggregate 3P anti-trafficking policy index. The identification of a spatial dependence effect rests on the assumption that the estimation model controls for confounding factors that may be correlated with the spatial lag. This is a demanding requirement. If, for example, policies generally become more stringent over time, then spatial lag variables will tend to be statistically significant predictors, but unless the general upward trend in policies is truly caused by spatial dependence, the estimated coefficient is upward biased. Similarly, although countries may make similar policy choices because of shared values or cultures predominating in a region for example, this doesn't necessarily mean that any true spatial dependence effect is at work via learning or emulation. Plümper and Neumayer (2010) argue that one must include the temporally lagged dependent variable and year-specific time fixed effects to account for common trends over time and common temporal shocks, while country fixed effects are needed to account for unobserved spatial heterogeneity and the spatial clustering of countries. Such stringent model specification minimizes, but cannot fully eliminate, the impact of potentially confounding factors. Fortunately, this model specification coincides with our preferred estimation equation (1). Spatial lag variables cannot be exogenous: If country $i$ were to be affected by the policies of other countries, the policies of other countries will also be affected by the policies chosen by country $i$. Rather than applying spatial maximum likelihood techniques, which are 
computationally difficult to implement, in Table 4 we exclusively use the system GMM estimator, additionally modeling the spatial lag variables as endogenous, similar to the temporally lagged dependent variable. Kukenova and Monteiro (2009) show that in Monte Carlo simulations, the system GMM estimator outperforms other estimators for spatial dynamic panel data models with one or more endogenous variables. For parsimony, we focus on the model specification from column (7) in Table 3.

As can be seen in Table 4, the effects of the control variables are not greatly affected by the inclusion of the spatial lags. Two of the spatial lags are significant at the five percent level at least, those being the contiguity and voting similarity-weighted ones. As argued above, this most likely captures an externality and a learning or emulation effect. Contiguous countries are exposed to the effect of stricter policies in neighboring countries, ${ }^{23}$ while countries look for cues from other countries with similar political views in their own policy design. In contrast, we find no evidence of a pressure effect since origin and transit countries do not seem to follow the policies of the countries for which they are major countries of transit or origin. If other contiguous countries increased the strictness of their anti-trafficking policies by one point in the previous year, then the country under observation is estimated to tighten its own policy by 0.232 points. In other words, the (short-run) speed of policy diffusion is about one quarter. The speed of policy diffusion is stronger for the spatial dependence effect, which weighs the influence of other countries by the degree to which they vote similarly on key issues at the UN General Assembly. A one point tightening of policies in similar countries in the previous year raises domestic policy stringency by roughly half a point. $^{24}$

Column 6 includes the spatial lags jointly rather than separately. In order to minimize the number of instruments in the regressions, we collapse the matrix of instruments as suggested in Roodman (2006), a practice we follow in all other specifications that jointly

\footnotetext{
${ }^{23}$ We alternatively weighted anti-trafficking policies with distance rather than contiguity. The resulting coefficient is not significant at conventional levels. This would suggest that the externality-effect is concentrated on geographically proximate countries, as captured by contiguity, with countries further away having no impact.

${ }^{24}$ Note that the sum of the coefficients of the spatial lag and the lagged dependent variable exceed unity in column (4) and some other model specifications reported in the following tables. This would imply an explosive process if interpreted as a non-changing long-run relationship. However, in the context of the limited time-series we focus on, the sum of the coefficients does not need to be below unity since diffusion might resemble an explosive process to start with, and then significantly slow down as time passes. Coefficients of similar size are commonly reported in the recent literature (e.g., Gassebner et al. 2011). In an analysis of the spread of corporate responsibility standards, Perkins and Neumayer (2010) find that an explosive diffusion process in a short panel turns into a non-explosive process when a panel of longer duration is analyzed.
} 
include all spatial lag variables. ${ }^{25}$ As can be seen, none of the lags remains significant at conventional levels, even though the insignificance is marginal in most cases. However, the voting-weighted lag remains significant in a specification where we do not collapse the instruments (not shown in the table). Overall, we prefer to rely on the specifications including one spatial lag at the time, but note that the significant coefficients might to some extent reflect the effects of other, omitted, lags.

In Table 5 we focus on the individual dimensions of the 3P index, starting with model specifications excluding the spatial lag variables. Estimation is done with GMM, despite the ordinal nature of the five-scale variables. This is because the problem of endogeneity is arguably more important than ignoring the ordinal nature of the dependent variables, in particular when we include the spatial lag variables below. ${ }^{26}$ We report specifications both including GDP per capita and U.S. aid and excluding them. Note that the Arellano-Bond test rejects the regressions focusing on the prosecution index (columns 3 and 4). We therefore include the second lag of the dependent variable (in columns 5 and 6). This specification is not rejected at conventional levels.

According to the results, GDP per capita and U.S. aid are not significant determinants of either of the constituent dimensions of anti-trafficking policies at conventional levels. The results for the remaining control variables are similar compared to the overall index. The lagged dependent variable is significant at the one percent level throughout. Control of corruption improves prevention and protection policies, but not those relating to prosecution. When controlling for the second lag of the dependent variable in the prosecution regressions, the same holds for democracy. Prevention and prosecution policies improve with better economic rights of women, at least at the ten percent level, but not with the share of women in the legislature, while the reverse holds for protection policies. ${ }^{27}$

Tables 6 and 7 include the spatial lags to the parsimonious specifications. The results for prevention and protection policies are reported in Table 6, those for prosecution policies are shown in Table 7 (again including and excluding, respectively, the second lag of the dependent variable). Results for prevention policies are similar to those of the 3P aggregate policy measure when we include the spatial lags individually (columns 1-5). In addition, there is evidence that countries follow policies of those belonging to the same civilizational group, arguably because of learning or emulation effects. When we include the spatial lags jointly (in

\footnotetext{
${ }^{25}$ It is necessary to limit the number of instruments because the power of the Sargan-Hansen test is low when many instruments are used (Bowsher 2002). Moreover, too many instruments might cause an overfitting of the instrumented variable.

${ }^{26}$ This is common in the recent literature (e.g., Dreher et al. 2010).

${ }^{27}$ Note however that the Hansen test is borderline in columns (7) and (8).
} 
column 6), only the voting-weighted lag remains significant at the ten percent level. Results on protection policies are striking in that all evidence for spatial dependence has disappeared, with the exception of the voting similarity weighted spatial lag variable (this holds when including the spatial lags individually and jointly). Interestingly, the impact of the contiguityweighted spatial lag variable is essentially zero. This is exactly what one would expect if our argument that contiguity captures an externality effect is correct. Stricter prevention and prosecution policies deflect flows of trafficked people onto other countries, thus generating an externality, however better victim protection policies do not deflect flows onto others - in fact, the opposite may even be the case, as we argued in the introduction.

Results on prosecution policies confirm that countries follow the policies of contiguous countries. When including the spatial lags separately, countries also seem to follow the policies of their major trading partners. Countries do not seem to follow policies of politically similar countries, as measured by the voting similarity weighting variable, but follow policies of countries belonging to their own civilization. As was the case before, we find no evidence for diffusion of policies via pressure from destination countries on their major transit and source countries (the relevant spatial lag is marginally significant in column (1), but insignificant if the second temporal lag of the dependent variable is included (as is required according to the result of the Arellano-Bond test). In the specification that includes all spatial lag variables, we even find a negative coefficient of the traffic link weighted spatial lag. This points toward a potential substitution effect: Stricter prosecution policies in destination countries would allow relevant major transit and origin countries to relax their prosecution policies, knowing that perpetrators are more strongly prosecuted elsewhere.

\section{Robustness Tests}

Finally, we perform two important robustness tests. First we estimate regional jackknife analyses, in which all countries of one particular region are dropped from the analysis at the time in order to test whether the results are driven by the presence of observations from a specific region in the sample. ${ }^{28}$

The results shown in Tables 8 and 9 are based on model specifications that include each spatial lag variable on its own. Starting with overall anti-trafficking policies in the upper part of Table 8, we find that the contiguity and voting-weighted spatial lag variables remain

\footnotetext{
${ }^{28} \mathrm{We}$ also examined the robustness of our results to the exclusion of countries where neither major flows of human trafficking originate from nor, respectively, go to. In both sets of regressions the t-statistics are lower compared to those reported above, but the results are generally similar. All results will be made available in the replication data.
} 
statistically significant independent of the region dropped from the sample. Strikingly, as the results reported in column 1 show, there is much more evidence for spatial dependence in anti-trafficking policies in developing countries. If the developed countries are dropped from the sample, there is additional evidence of anti-trafficking policies diffusing via trade links and civilizational similarities. For prevention policies, the contiguity and voting-weighted spatial lags remain statistically significant at conventional levels in most jackknife specifications, but it is only diffusion via reference to countries that belong to the same civilization for which there is almost consistent evidence, with the exception of the model excluding countries from North Africa and the Middle East. ${ }^{29}$

For protection policies, the regional jackknife estimation results reported in the upper part of Table 9 suggest that the voting-weighted spatial lag variable is a robust predictor. There is again some evidence for diffusion via civilizational belonging, but the respective spatial lag variable is only significant in three out of seven estimations. Results for prosecution policies largely confirm the existence of spatial dependence working via contiguity, trade and civilizational links. Interestingly, in two cases we find again negative coefficient signs for the traffic link-weighted spatial lag variable, which we found already in table 7, but only for the specification that included all spatial lag variables simultaneously. This suggests that the effect reported for table 7 was not entirely due to multi-collinearity problems. Dropping either Eastern and Central European or Sub-Saharan African countries from the sample, we find that stronger prosecution policies in destination countries have a negative (or substitution) effect on prosecution policies in major transit and origin countries, such that the latter relax their own policies knowing that perpetrators are more vigorously prosecuted in destination countries. This result is not robust to other model specifications and we do not want to make too much of it, but we regard this as one of the findings that deserves closer attention in future research.

Next we turn to the robustness of our results to the choice of control variables. As the theory and empirics of anti-trafficking policies have only begun to be seriously addressed recently, there is still considerable uncertainty about which explanatory variables to include. To examine the sensitivity of the results reported above, we therefore employ (variants of) the extreme bounds analysis (EBA), as proposed by Leamer (1983) and Levine and Renelt (1992), as our second test for robustness. EBA enables us to examine whether the spatial lags are

\footnotetext{
${ }^{29}$ Note that the specification excluding the Middle East and North Africa suffers from a potential endogeneity problem, the p-value of the Hansen test being 0.09, while the Hansen tests in all other samples do not reject the specifications at conventional levels of significance.
} 
indeed robust determinants of anti-trafficking policies, independent of which additional variables are also included in the set of control variables.

To conduct an EBA, equations of the following general form are estimated:

$$
y_{i, t}=\beta_{M} M+\beta_{F} F+\beta_{Z} Z+v,
$$

where $y_{i, t}$ again represents our measures of anti-trafficking policies in country $i$ at year $t, M$ is a vector of "commonly accepted" explanatory variables and $F$ is a vector containing the variables of interest (i.e., each spatial lag on its own). The vector $Z$ contains up to three possible additional explanatory variables (as in Levine and Renelt 1992), which, according to the broader literature, are related to the dependent variable. The error term is $v$.

The EBA-test for a variable in $F$ states that if the lower extreme bound for $\beta_{F}-$ i.e., the lowest value for $\beta_{F}$ minus two standard deviations - is negative, while the upper extreme bound for $\beta_{F}$ - i.e., the highest value for $\beta_{F}$ plus two standard deviations - is positive, the variable $F$ is not robustly related to anti-trafficking policies.

Sala-i-Martin (1997) argues that this criterion is far too restrictive for any variable to pass the test. If the distribution of the parameter of interest has both positive and negative support, then a researcher is bound to find at least one regression model for which the estimated coefficient changes sign if enough regressions are run. Consequently, not only do we report the extreme bounds, but also the percentage of the regressions in which the coefficient of the variable $F$ is statistically different from zero at the five percent level.

Moreover, instead of merely analyzing the extreme bounds of the estimates for the coefficient of a particular variable, we follow Sala-i-Martin's (1997) recommended procedure and analyze the entire distribution. Accordingly, we also report the unweighted parameter estimate of $\beta_{F}$ and its standard error, as well as the unweighted cumulative distribution function, $\mathrm{CDF}(0)$. The latter represents the proportion of the cumulative distribution function lying on each side of zero. $\operatorname{CDF}(0)$ indicates the larger of the areas under the density function (either above or below zero). Therefore, $\operatorname{CDF}(0)$ always lies between 0.5 and 1.0.

The vector $M$ contains the same variables as the regressions in the tables above. In accordance with the previous literature, to test for the robustness of our results we have collected a total of 14 additional variables which could potentially influence the level of antitrafficking policies. All variables and their sources are listed in Appendix B.

Our choice of variables follows the three most recent papers on the determinants of anti-trafficking policies (Avdeyeva 2010; Bartilow 2010; Simmons and Lloyd 2010). As 
Bartilow (2010) and Simmons and Lloyd (2010) argue, a generally well-developed legal system and the enforcement of the law can be an important determinant of the adoption and implementation of anti-trafficking laws. We therefore use the rule of law indicators provided by the ICRG, as well as the World Bank Governance Indicators, to test for the robustness of our results.

According to Bartilow, women's social rights can further capture the gender dimension of human trafficking, while Simmons and Lloyd point out that worker's rights are a good indicator of a country's tolerance of exploitative, forced labor. ${ }^{30}$ As the issue of human trafficking can be brought into the public spotlight through the media, the level of media freedom, measured by Freedom House, has the potential to influence relevant policy operations (Simmons and Lloyd). Membership in a prestigious club can also explain the compliant behavior of certain countries, in terms of their concern for their reputation. We therefore include a dummy for EU membership, following Avdeyeva (2010). The degree of economic, social and political globalization, measured by the KOF Index of Globalization (Dreher et al. 2008), may also capture associations between the spread of anti-trafficking policies and countries' economic, social and political exposure to the world. This is broadly suggested by Avdeyeva (2010) and Simmons and Lloyd (2010). Inflows of remittances (as a percentage of GDP) can indicate the economic interests a country may have in sending its nationals abroad to work (Simmons and Lloyd). Furthermore, we add those variables already included in Table 3, but excluded from later tables due to their insignificance: (log) per capita GDP, the amount of U.S aid inflows (as a percentage of GDP) and protocol ratification.

The results for the EBA models are presented in Table 10. Following Sala-i-Martin, we use a $\operatorname{CDF}(0)$ value of 0.90 as the threshold above which we consider variables to be robust. ${ }^{31}$ We report the results in four panels, one for each dependent variable. The upper-left panel of Table 8 shows the results for the overall anti-trafficking index. As can be seen, the lagged dependent variable is clearly a robust determinant of current levels, with the CDF(0) being equal to one. Among the control variables, democracy and women's economic rights exceed the critical threshold. In line with Table 4 above, the contiguity-weighted spatial lag

\footnotetext{
${ }^{30}$ Both dimensions are measured with data taken from Cingranelli and Richards (2008).

${ }^{31}$ Sala-i-Martin (1997) proposes using the (integrated) likelihood to construct a weighted CDF(0). However, the varying number of observations in the regressions due to missing observations in some of the variables poses a problem. Sturm and de Haan (2001) show that as a result this goodness of fit measure may not be a good indicator of the probability that a model is the true model and the weights constructed in this way are not equivariant for linear transformations in the dependent variable. Hence, changing scales will result in rather different outcomes and conclusions. We therefore restrict our attention to the unweighted version. Furthermore, for technical reasons - in particular our unbalanced panel setup - we are unable to use the extension of this approach called Bayesian Averaging of Classical Estimates (BACE) as introduced by Sala-i-Martin, Doppelhofer and Miller (2004).
} 
turns out to be a robust determinant of anti-trafficking policies, with a $\operatorname{CDF}(0)$ of 0.95 . The effect of the second spatial lag that was significant in Table 4 - voting-weighted - does not turn out to be a robust determinant of the index when we include the various combinations of the explanatory variables. However, given that the correct model specification is unknown, it is worth noting that the CDF will potentially reflect a combination of correctly specified models and misspecified ones. Moreover, the CDF will also partly reflect models with a lower number of observations due to missing data for some of the explanatory variables. While we can have confidence in the robustness of a variable with a $\operatorname{CDF}(0)$ exceeding 0.9 , we cannot know for sure whether those below this threshold are truly insignificant predictors of the dependent variable.

The remaining panels of Table 10 test the robustness of the models for the individual dimensions of the anti-trafficking index. In summary, some of our previous results turn out to be robust. Regarding prevention, the civilization-weighted spatial lag is highly robust, while the contiguity and voting-weighted spatial lags are not. With respect to protection, the votingweighted lag is robust, while for prosecution policies, the contiguity-weighted lag survives the EBA test and the trade-weighted lag is very close to the threshold of a $\operatorname{CDF}(0)$ exceeding 0.9 . Thus conclusively, we continue to find evidence for spatial dependence in anti-trafficking policies even if the spatial lag variables are subjected to this rather demanding robustness test.

\section{Conclusion}

In this paper, we have introduced new measures of countries' policies aimed at combating international trafficking in human beings. Our aggregate policy index is fine-grained and based on the consistent coding of a wide range of informational sources, while our disaggregated measures capture the three different fundamental dimensions of anti-trafficking policies, namely prevention, protection and prosecution. Scholars may wish to use the aggregate index if they are interested in overall policies, but we strongly recommend that future research analyzes the different dimensions of overall policies separately and in greater detail than we could do here. For example, protection policies mainly protect victims, while prosecution policies mainly target the perpetrators. Why countries choose to pursue one type of policy rather than the other deserves closer scrutiny.

Besides introducing novel data to the still recent, yet burgeoning literature on human trafficking, we have also contributed to the analysis of anti-trafficking policies by analyzing the effect of spatial dependence in this policy domain, which the extant literature has so far neglected. Domestic policies, we have argued, will be affected by policies abroad because of 
pressure, externalities, learning or emulation effects. Our results only partly corroborate these hypotheses. On the one hand, we find no evidence for anti-trafficking policies diffusing via pressure exerted by destination countries onto their major transit or origin countries. Our results suggest that anti-trafficking policies are an area where destination countries seem unwilling, or, even if they are willing, are unable to pressure the countries where the majority of victims of human trafficking come from or are channeled through, to change their policies. On the other hand, we find consistent evidence for externality effects - with the exception of protection policies, for which one would not expect such an effect. We thus find that stricter policies in contiguous countries, or sometimes in major trading partners, are followed by stricter domestic policies as well. The most likely explanation is simple: Stricter policies create negative externalities on neighboring countries and trading partners, exacerbating their problems in dealing with human trafficking as a result. Contiguity and trade might also partially capture learning or emulation channels of diffusion. In fact, we find robust evidence that countries look towards those with similar political views, as proxied by our connectivity variable of voting similarity on key issues in the UN General Assembly. This is also the case for countries sharing similar cultural values, as proxied by our connectivity variable measuring civilizational belonging. All in all, we find robust evidence that countries do not operate in isolation when deciding on anti-trafficking policies, being affected by the prior choices of other countries on which their policy choices spatially depend. 


\section{References}

Akee, Randall, Arjun Bedi, Arnab K. Basu and Nancy H. Chau, 2010, Transnational Trafficking, Law Enforcement and Victim Protection: A Middleman’s Perspective, mimeo, Department of Economics, Cornell University.

Arellano, Manuel and Olympia Bover, 1995, Another look at the instrumental variable estimation of error-components models, Journal of Econometrics 68: 29-51.

Auriol, Emmanuelle and Alice Mesnard. 2010, Fighting Human Smuggling: Legalization or Repression?. Presented at the European Development Research Network Conference (Nov. 2010. Paris. France).

Avdeyeva, Olga 2010, Trafficking in Persons: Why Do States Comply with International Treaties?, paper presented at the $51^{\text {st }}$ International Studies Association Annual Convention, San Francisco, February, New Orleans, LA.

Bartilow, Horace, 2010, Gender Representation and International Compliance Against Human Trafficking, mimeo.

Belser, Patrick, 2005, Forced Labour and Human Trafficking: Estimating the Profits, Working Paper (Declaration/WP/42/2005). International Labour Office. Geneva.

Bennett, D. Scott and Allan C. Stam. 2010. Contiguity Data set. http://eugenesoftware.org/

Bjørnskov, Christian, 2010, Do Elites Benefit from Democracy and Foreign Aid in

Developing Countries?, Journal of Development Economics 92(2): 115-124.

Blonigen, Bruce A., Ronald B. Davies, Helen T. Naughton and Glen R. Waddell, 2007, FDI in Space: Spatial Autoregressive relationships in Foreign Direct Investment. European Economic Review 51: 1303-1325.

Blundell, Richard and Stephen Bond, 1998, Initial conditions and moment restrictions in dynamic panel data models, Journal of Econometrics 87: 115-43.

Bowsher, Clive G., 2002, On Testing Overidentifying Restrictions in Dynamic Panel Data Models, Economics Letters 77, 2: 211-220.

Cameron, Sally and Edward Newman, 2008, Trafficking in Humans: Structural Factors, in Trafficking in Humans: Social, Cultural and Political Dimensions, edited by Sally Cameron and Edward Newman. United Nations University Press.

Chattopadhyay and Duflo, 2004, Women as Policy Makers: Evidence from a Randomized policy experiment in India, Econometrica 72 (5): 1409-1443.

Cho, Seo-Young and Krishna Chaitanya Vadlamannati, 2011. Compliance for Big Brothers An Empirical Analysis on the Impact of the Anti-trafficking Protocol, mimeo. University of Goettingen. 
Cingranelli, David and David Richards, 2008, The Cingranelli-Richards (CIRI) Human Rights Data Project Coding Manual, http://ciri.binghamton.edu/.

de Soysa, Indra and Krishna Chaitanya Vadlamannati, 2010, Does Being Bound Together Liberate or Suffocate? The Effects of Economic, Social, and Political Globalization on Human Rights, 1981-2005, Kyklos (forthcoming).

Di Tommaso, Maria L., Isilda Shima, Steinar Strøm and Francesca Bettio, 2009, As Bad as it gets: Well-being Deprivation of Sexually Exploited Trafficked Women, European Journal of Political Economy 25: 143-162.

Dixon, William, 1993, Democracy and the Management of International Conflict, Journal of Conflict Resolution 37 (1): 42-68.

Dreher, Axel, Noel Gaston and Pim Martens, 2008, Measuring Globalization - Gauging its Consequences, New York: Springer.

Dreher, Axel, Martin Gassebner and Lars-H.R. Siemers, 2010, Does Terror Threaten Human Rights? Evidence from Panel Data, Journal of Law and Economics 53 (1): 65-93.

Eichengreen Barry and Leblang, David, 2008, Democracy and Globalization. Economics \& Politics 20(3): 289-334.

Elkins, Zachary and Beth Simmons, 2005, On Waves, Clusters, and Diffusion: A Conceptual Framework, The Annals of American Academy. AAPSS 598: 33-51.

ERS International Macroeconomics Data Set, 2010, http://www.ers.usda.gov/Data/

European Union, 2010, http://europa.eu/abc/european_countries/index_en.htm

Freedom House, 2010, Freedom of the Press, http://www.freedomhouse.org/

Friebel, Guido and Sergei Guriev, 2006, Smuggling Humans: A Theory of Debt-Financed Migration, Journal of the European Economic Association 4(6):1085-1111

Gassebner, Martin, Gaston, Noel and Lamla, Michael, 2011, The Inverse Domino Effect: Are Economic Reforms Contagious? International Economic Review, forthcoming.

Gauri, Varun, 2011, The Cost of Complying with Human Rights Treaties: The Convention on the Rights of the Child and Basic Immunization, Review of International Organizations 6(1): 33-56.

Greenhill, Brian, Layna Mosley and Aseem Prakash, 2009, Trade-based Diffusion of Labor Rights: A Panel Study, 1986-2002, American Political Science Review 103(4):669690.

Hathaway, Oona, 2007, Why do Countries Commit to Human Rights Treaties?, Journal of Conflict Resolution 51 (4): 588-621.

Interpol, 2009, http://www.interpol.int/Public/THB/ 
International Country Risk Guide, 2009, http://www.prsgroup.com/, PRS Group.

Kaufmann, Daniel, Kraay, Aart and Massimo Mastruzzi, 2009, Governance Matters VIII: Aggregate and Individual Governance Indicators 1996-2008, Policy Research Working Paper Series 4978, The World Bank, Washington DC.

Kilby, Christopher, 2009, Donor Influence in International Financial Institutions: Deciphering What Alignment Measures Measure. Paper presented at the Political Economy of International Organizations Meeting. Geneva, 2009.

Kukenova, Michael \& Monteiro, Jose-Antonio, 2009, Spatial Dynamic Panel Model and System GMM: a Monte Carlo investigation, mimeo.

Lancaster, Tony, 2000, The Incidental Parameter Problem Since 1948, Journal of Econometrics 95: 391-413.

Leamer, Edward E., 1983, Let`s Take the Con Out of Econometrics, American Economic Review 73(1): 31-43.

Levine, Ross and David Renelt, 1992, A Sensitivity Analysis of Cross-Country Growth Regressions, American Economic Review, 82(4): 942-63.

Mahmoud, Toman O. and Christoph Trebesch, 2010, The Economics of Human Trafficking and Labor Migration: Micro-evidence from Eastern Europe, Journal of Comparative Economics 38(2): 173-188.

Marshall, Monty G. and Keith Jaggers, 2009, Polity IV Project: Political Regime Characteristics and Transitions, 1800-2009, Polity IV.

McGillivray, Mark and Howard White, 1993, Measuring Development? The UNDP's Human Development Index, Journal of International Development 5(2): 183-192.

Neumayer, Eric, 2005, Do international human rights treaties improve respect for human rights?, Journal of Conflict Resolution, 49: 925-953.

Neumayer, Eric and Thomas Plümper, 2010, Spatial Effects in Dyadic Data, International Organization 61(1): 145-166.

Nickell, Stephen J., 1981, Biases in Dynamic Models with Fixed Effects, Econometrica 49: 1417-1426.

OECD, 2010, Aid Statistics, http://www.oecd.org/statisticsdata/

Perkins, Richard and Eric Neumayer, 2010, Geographic Variations in the Early Diffusion of Corporate Voluntary Standards: Comparing ISO14001 and the Global Compact, Environment and Planning A, 42 (2): 347-365

Pitlik, Hans, 2007, A Race to Liberalization? Diffusion of Economic Policy Reform among OECD-Economies, Public Choice 132: 159-178. 
Plümper, Thomas and Eric Neumayer, 2010, Model Specification in the Analysis of Spatial Dependence, European Journal of Political Research 49: 418-442.

Roodman, David, 2005, xtabond2: Stata Module to Extend xtabond Dynamic Panel Data Estimator. Center for Global Development, Washington, D.C.

Roodman, David, 2006, How to Do xtabond2: An Introduction to "Difference" and "System" GMM.

Roodman, David, 2007, A Note on the Theme of Too Many Instruments. Center for Global Development, Washington, D.C.

Russett, Bruce M., John R. Oneal, and Michaelene Cox, 2000, Clash of Civilizations, or Realism and Liberalism déjà vu? Some Evidence. Journal of Peace Research 37(5): 583-608.

Sala-i-Martin, Xavier, 1997, I just Ran Four Million Regressions, American Economic Review, 87(2): 178-183.

Sala-i-Martin, Xavier, Gernot Doppelhofer and Ronald I. Miller, 2004, Determinants of longterm growth: A Bayesian averaging of classical estimates (BACE) approach, American Economic Review 94 (4): 813-835.

Simmons, Beth, 1998, Compliance with International Agreements, Annual Review of Political Science 1:75-93

Simmons, Beth and Zachary Elkins, 2004, The Globalization of Liberalization: Policy Diffusion in the International Political Economy. American Political Science Review. 98(1): 171-189.

Simmons, Beth and Paulette Lloyd, 2010, Subjective Frames and Rational Choice: Transnational Crime and the Case of Human Trafficking, mimeo. Government Department, Harvard University.

Slaughter, Anne-Marie, 1995, International Law in a World of Liberal States, European Journal of International Law 6:503-38.

Sturm, Jan-Egbert and Jakob de Haan, 2001, How Robust is Sala-i-Martin's Robustness Analysis, University of Groningen, mimeo.

The United States Congress, 2000, The Victims of Trafficking and Violence Protection Act of 2000, in Public Law 106-386, Washington D.C: United States Congress.

United Nations, 2000, Convention against Transnational Organized Crime and its Protocol to Prevent, Suppress and Punish Trafficking in Persons, especially Women and Children, New York.

United Nations Commodity Trade Statistics Database (COMTRADE), 2010. 
United Nations Office on Drugs and Crime, 2006, Trafficking in Persons Global Pattern. Vienna.

United Nations Office on Drugs and Crime, 2009 Global Report on Trafficking in Persons. Vienna.

United Nations Office on Drugs and Crime, 2010 Signatories to the United Nations Convention against Transnational Crime and its Protocols, http://www.unodc.org/

United States Department of State, 2001-2010, Annual Reports on Trafficking in Persons, Washington D.C.

United States, Government Accountability Office (GAO), 2006, Human Trafficking: Better Data, Strategy, and Reporting Needed to Enhance U.S. Anti-trafficking Efforts Abroad. In Report to the Chairman, Committee on the Judiciary and the Chairman, Committee on International Relations, House of Representative, Washington DC.

Voeten, Erik and Adis Merdzanovic, 2009, United Nations General Assembly Voting Data. hdl:1902.1/12379 UNF:3:Hpf6qOkDdzzvXF9m66yLTg==.

Washington, Ebonya, 2006, Female Socialization: How Daughters Affect Their Legislator Fathers' Voting on Women's Issues, NBER Working Paper No. 11924.

Windmeijer, Frank, 2005, A Finite Sample Correction for the Variance of Linear Efficient Two-step GMM Estimators, Journal of Econometrics 126: 25-51.

Wooldridge, Jeffrey, 2002, Econometric Analysis of Cross Section and Panel Data, MIT Press.

World Bank Gender Statistics, 2010, http://data.worldbank.org/data-catalog/gender-statistics

World Development Indicator, 2009, http://data.worldbank.org/indicator/ 
Figure 1. Compliance with anti-trafficking policies (global sample), 2000-2009
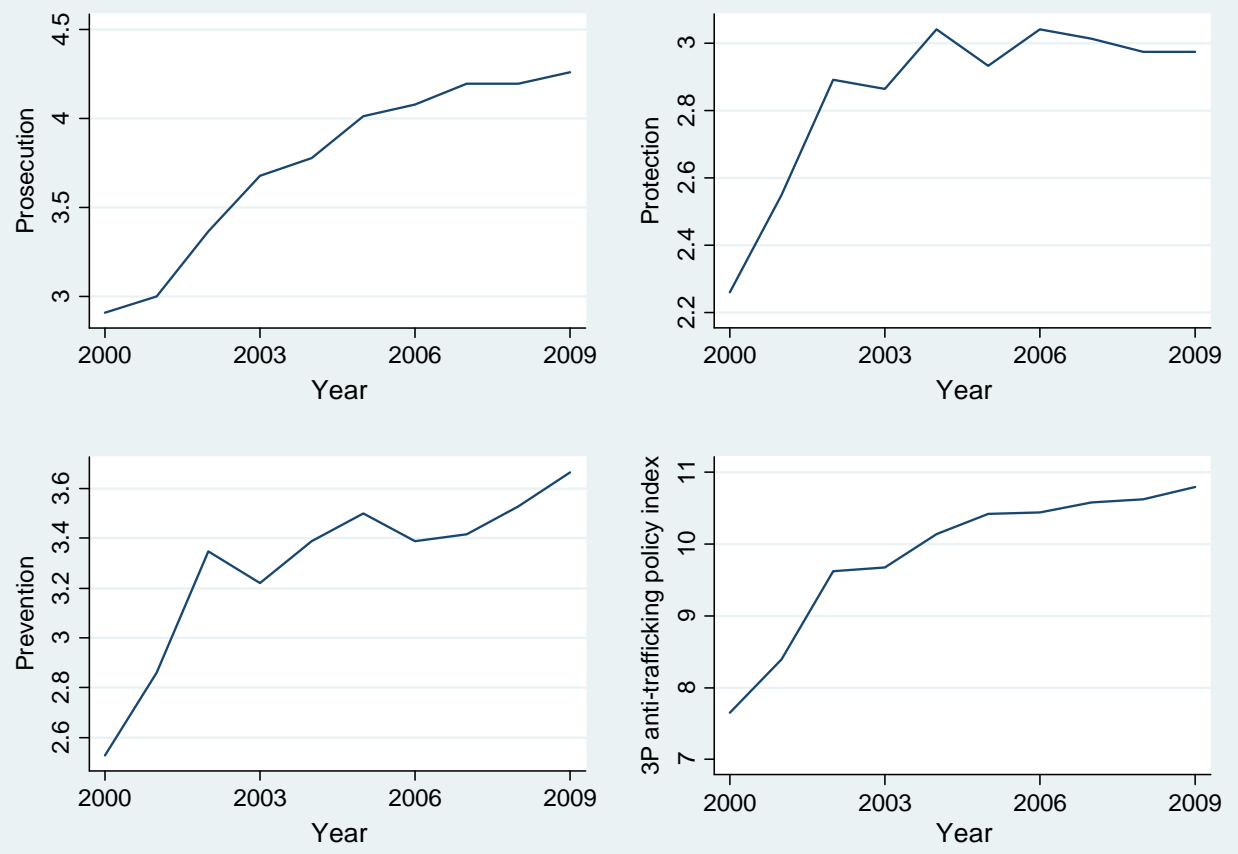

Note: The unweighted averages use balanced country samples. 
Figure 2: Compliance with anti-trafficking policies across regions and time

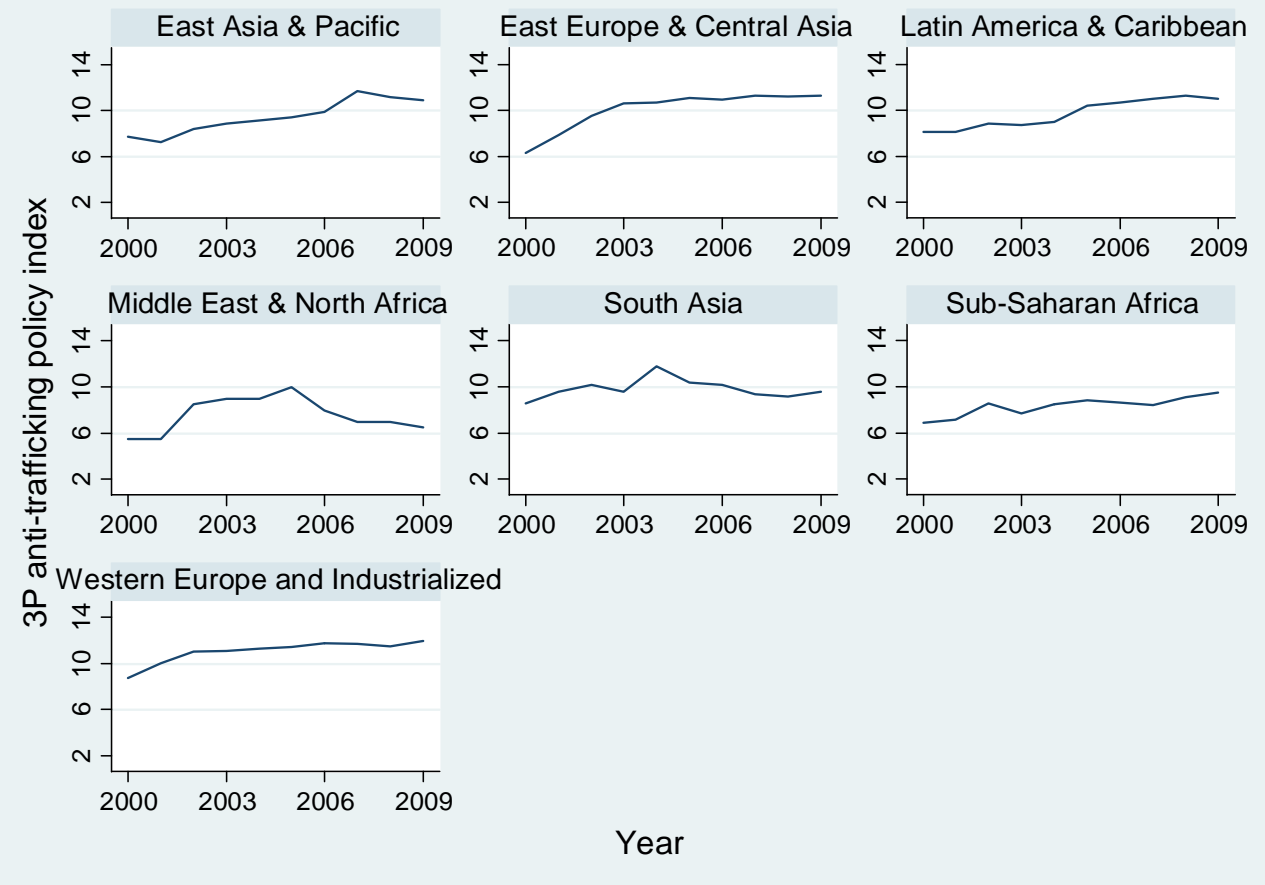

Note: The unweighted averages use balanced country samples.

Figure 3. Compliance with anti-trafficking policies across income groups and time

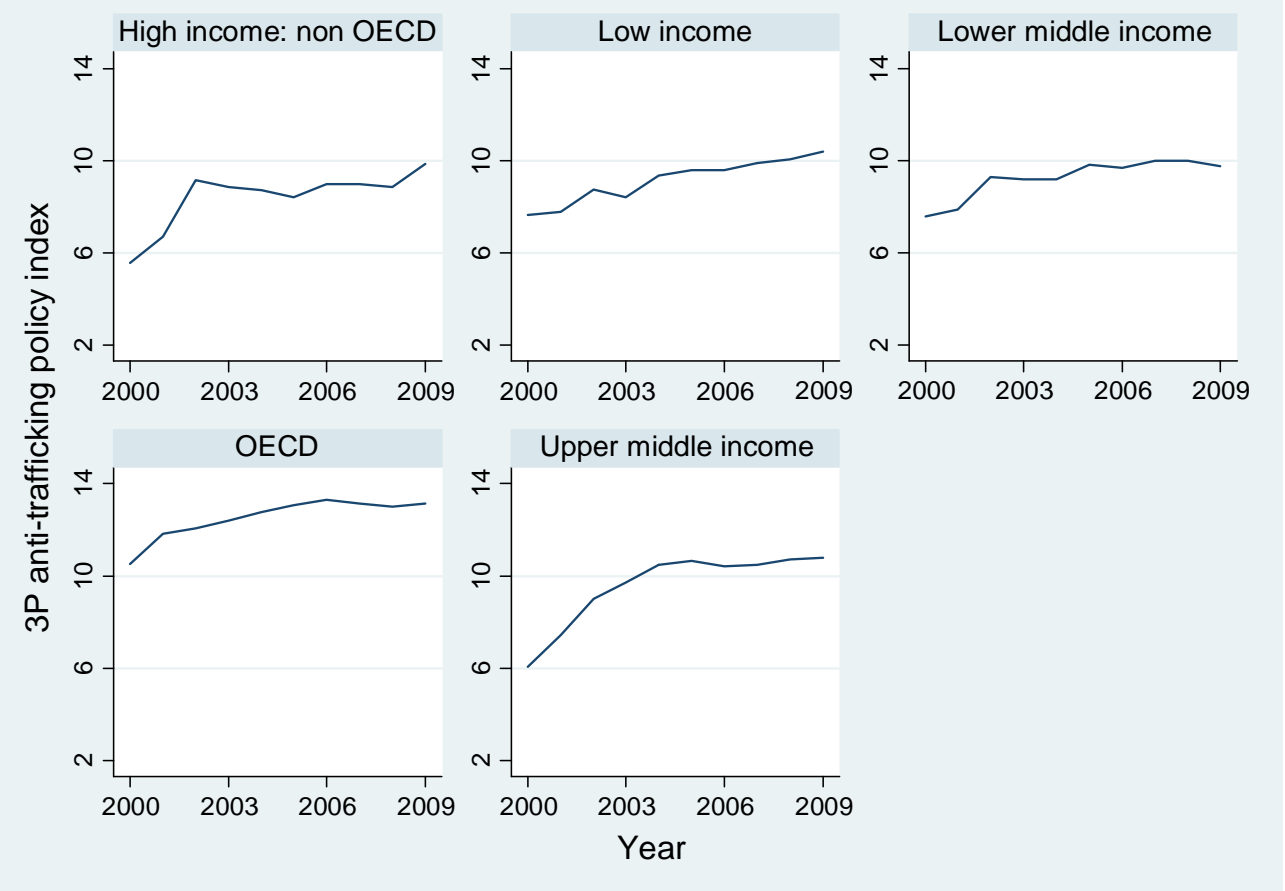

Note: The unweighted averages refer to balanced country samples. 
Table 1: Global and Regional Average Scores of 3Ps (2000, 2005 and 2009)

\begin{tabular}{l|llllllllllllll}
\hline & \multicolumn{3}{|c}{ Prosecution } & \multicolumn{3}{c}{ Protection } & \multicolumn{3}{c}{ Prevention } & \multicolumn{3}{c}{ Aggregate 3Ps } \\
& 2000 & 2005 & 2009 & 2000 & 2005 & 2009 & 2000 & 2005 & 2009 & 2000 & 2005 & 2009 \\
& & & & & & & & & & & & \\
\hline Worldwide & 2.89 & 3.55 & 3.76 & 2.24 & 2.79 & 2.78 & 2.49 & 3.19 & 3.28 & 7.58 & 9.61 & 9.85 \\
& $(81)$ & $(159)$ & $(177)$ & $(78)$ & $(156)$ & $(176)$ & $(78)$ & $(159)$ & $(176)$ & $(74)$ & $(156)$ & $(175)$ \\
& & & & & & & & & & & & \\
East Asia & 2.63 & 3.33 & 3.76 & 2.25 & 2.33 & 2.29 & 2.71 & 2.83 & 2.76 & 7.71 & 8.50 & 8.82 \\
/ Pacific & $(8)$ & $(12)$ & $(17)$ & $(8)$ & $(12)$ & $(17)$ & $(7)$ & $(12)$ & $(17)$ & $(7)$ & $(12)$ & $(17)$ \\
& & & & & & & & & & & & \\
Eastern Europe & 2.70 & 4.50 & 4.67 & 1.63 & 2.82 & 3.17 & 2.19 & 3.42 & 3.50 & 6.40 & 11.0 & 11.3 \\
/Central Asia & $(17)$ & $(24)$ & $(24)$ & $(16)$ & $(23)$ & $(24)$ & $(16)$ & $(24)$ & $(24)$ & $(15)$ & $(23)$ & $(24)$ \\
& & & & & & & & & & & & \\
Latin America / & 3.44 & 3.48 & 3.96 & 2.22 & 2.78 & 3.17 & 2.5 & 2.96 & 3.21 & 8.13 & 9.22 & 10.6 \\
Caribbean & $(9)$ & $(23)$ & $(25)$ & $(9)$ & $(23)$ & $(24)$ & $(8)$ & $(23)$ & $(24)$ & $(8)$ & $(23)$ & $(23)$ \\
& & & & & & & & & & & & \\
Middle East & 1.41 & 2.50 & 2.58 & 1.50 & 1.83 & 1.32 & 2.00 & 2.25 & 2.25 & 5.50 & 6.58 & 6.25 \\
/North Africa & $(2)$ & $(12)$ & $(12)$ & $(2)$ & $(12)$ & $(12)$ & $(2)$ & $(12)$ & $(12)$ & $(2)$ & $(12)$ & $(12)$ \\
& & & & & & & & & & & & \\
Western Europe & 3.30 & 4.02 & 4.17 & 2.50 & 3.31 & 3.25 & 2.91 & 3.64 & 3.77 & 8.67 & 11 & 11.2 \\
/OECD & $(23)$ & $(42)$ & $(48)$ & $(22)$ & $(42)$ & $(48)$ & $(23)$ & $(42)$ & $(48)$ & $(21)$ & $(42)$ & $(48)$ \\
& & & & & & & & & & & & \\
South Asia & 3.6 & 4.33 & 3.43 & 2.6 & 2.50 & 2.00 & 2.4 & 3.17 & 3.00 & 8.6 & 10 & 8.43 \\
& $(5)$ & $(6)$ & $(7)$ & $(5)$ & $(6)$ & $(7)$ & $(5)$ & $(6)$ & $(7)$ & $(5)$ & $(6)$ & $(7)$ \\
Sub-Saharan & & & & & & & & & & & & \\
Africa & 2.25 & 2.79 & 3.02 & 2.47 & 2.72 & 2.50 & 2.19 & 3.10 & 3.14 & 6.87 & 8.78 & 8.66 \\
$(16)$ & $(38)$ & $(42)$ & $(15)$ & $(36)$ & $(42)$ & $(16)$ & $(38)$ & $(42)$ & $(15)$ & $(36)$ & $(42)$ \\
\hline Notes: Num
\end{tabular}

Notes: Number of countries in parentheses.

Table 2: Correlation across prosecution, protection, prevention and the tier-ranking

\begin{tabular}{l|lllll}
\hline & Prosecution & Protection & Prevention & Aggregate 3P & Tier-ranking \\
\hline Prosecution & 1.00 & & & & \\
Protection & 0.51 & 1.00 & & & \\
Prevention & 0.52 & 0.64 & 1.00 & & \\
Aggregate 3P & 0.83 & 0.85 & 0.84 & 1.00 & 1.00 \\
Tier-ranking & 0.53 & 0.63 & 0.66 & 0.72 & \\
\hline
\end{tabular}

Note: A lower tier-ranking score reflects better compliance on the original scale, so we reverse the scale here. 
Table 3: Anti-Trafficking Policies (Aggregate 3Ps and Tier-ranking), 2002-2009

\begin{tabular}{|c|c|c|c|c|c|c|c|}
\hline & $(1)$ & $(2)$ & $(3)$ & $(4)$ & (5) & (6) & (7) \\
\hline \multirow[t]{2}{*}{ dependent variable, $\mathrm{t}-1$} & $2.060 * * *$ & $0.610 * * *$ & $0.759 * * *$ & $0.302^{* * *}$ & $0.511 * * *$ & $0.302^{* * *}$ & $0.525^{* * *}$ \\
\hline & $(12.52)$ & $(23.70)$ & (33.88) & (8.74) & (7.17) & (8.96) & $(7.48)$ \\
\hline \multirow[t]{2}{*}{ control of corruption } & $0.458 * * *$ & 0.106 & 0.095 & $0.961^{* *}$ & $0.331^{* *}$ & $0.833^{*}$ & $0.385^{* * *}$ \\
\hline & $(4.53)$ & $(1.58)$ & $(1.20)$ & $(2.14)$ & $(2.20)$ & $(1.89)$ & $(4.06)$ \\
\hline \multirow[t]{2}{*}{ democracy } & $0.025^{* *}$ & $0.024 * * *$ & $0.033^{* * *}$ & $-0.067^{*}$ & $0.058^{* * *}$ & $-0.076 * *$ & $0.069 * * *$ \\
\hline & $(2.13)$ & $(3.25)$ & $(3.46)$ & $(1.89)$ & $(3.05)$ & $(2.01)$ & $(3.34)$ \\
\hline \multirow[t]{2}{*}{ women legislators (percent) } & $0.010^{*}$ & $0.008 * *$ & $0.008 *$ & -0.011 & 0.014 & -0.005 & 0.007 \\
\hline & $(1.74)$ & $(2.17)$ & $(1.79)$ & $(0.80)$ & $(1.64)$ & $(0.34)$ & $(0.79)$ \\
\hline \multirow[t]{2}{*}{ women economic rights } & $0.196 *$ & $0.126 * *$ & $0.151^{* *}$ & $0.156^{*}$ & $0.288^{* * *}$ & $0.150^{*}$ & $0.239 * *$ \\
\hline & $(1.93)$ & $(2.27)$ & $(2.23)$ & $(1.80)$ & $(3.30)$ & $(1.77)$ & $(2.49)$ \\
\hline \multirow[t]{2}{*}{ international regime membership } & 0.138 & 0.070 & 0.105 & 0.133 & 0.108 & & \\
\hline & (1.08) & (0.98) & (1.17) & $(0.75)$ & $(0.66)$ & & \\
\hline \multirow[t]{2}{*}{ (log) GDP p.c. } & -0.064 & 0.029 & 0.018 & 0.087 & 0.037 & & \\
\hline & $(1.12)$ & $(0.73)$ & $(0.36)$ & $(0.28)$ & $(0.39)$ & & \\
\hline \multirow[t]{2}{*}{ US aid (percent of GDP) } & 0.004 & 0.012 & 0.011 & -0.008 & -0.002 & & \\
\hline & $(0.23)$ & $(1.31)$ & $(0.93)$ & $(0.50)$ & $(0.11)$ & & \\
\hline Method & oprobit & oprobit & OLS & OLS, fe & GMM & OLS, fe & GMM \\
\hline Number of observations & 918 & 943 & 943 & 943 & 943 & 983 & 983 \\
\hline Number of countries & 143 & 145 & 145 & 145 & 145 & 150 & 150 \\
\hline Adj. R-Squared & 0.54 & 0.31 & & & & & \\
\hline Number of instruments & & & & & 60 & & 57 \\
\hline Arellano-Bond test (Pr>z) & & & & & 0.40 & & 0.27 \\
\hline Hansen test (Prob>chi2) & & & & & 0.55 & & 0.59 \\
\hline
\end{tabular}

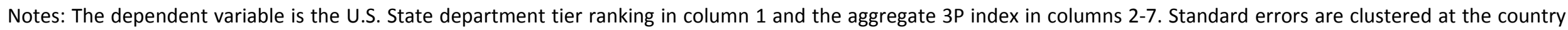
level. A dummy for each year is included. Absolute $z$-statistics in parentheses; $*(* *, * *)$ indicates significance at $10(5,1)$ percent level. 
Table 4: Anti-Trafficking Policies (Aggregate 3Ps) with spatial lags, GMM, 2002-2009

\begin{tabular}{|c|c|c|c|c|c|c|}
\hline & $(1)$ & $(2)$ & (3) & (4) & (5) & $(6)$ \\
\hline \multirow[t]{2}{*}{ dependent variable, $\mathrm{t}-1$} & $0.538 * * *$ & $0.487^{* * *}$ & $0.606 * * *$ & $0.609 * * *$ & $0.563^{* * *}$ & $0.471^{* * *}$ \\
\hline & $(7.62)$ & $(7.01)$ & $(8.63)$ & $(9.32)$ & $(7.44)$ & $(5.71)$ \\
\hline \multirow[t]{2}{*}{ control of corruption } & $0.432 * * *$ & $0.397^{* * *}$ & $0.222 * *$ & $0.237^{* * *}$ & $0.349 * * *$ & $0.537 * * *$ \\
\hline & (3.78) & $(3.67)$ & $(2.09)$ & $(2.89)$ & $(3.41)$ & $(3.05)$ \\
\hline \multirow[t]{2}{*}{ democracy } & $0.069 * * *$ & $0.053^{* * *}$ & $0.060 * * *$ & $0.046^{* * *}$ & $0.068 * * *$ & $0.061^{* *}$ \\
\hline & (3.19) & $(2.60)$ & $(2.81)$ & $(2.60)$ & (3.21) & $(2.04)$ \\
\hline \multirow[t]{2}{*}{ women legislators (percent) } & -0.005 & 0.001 & 0.005 & 0.007 & 0.002 & -0.009 \\
\hline & $(0.63)$ & $(0.09)$ & $(0.65)$ & $(0.91)$ & $(0.22)$ & $(0.69)$ \\
\hline \multirow[t]{2}{*}{ women economic rights } & 0.168 & $0.184^{*}$ & $0.250 * * *$ & $0.194^{* *}$ & $0.218^{* *}$ & $0.233^{*}$ \\
\hline & $(1.58)$ & $(1.78)$ & $(2.59)$ & $(2.03)$ & $(2.32)$ & $(1.79)$ \\
\hline \multirow[t]{2}{*}{ spatial lag, traffic link-weighted } & 0.051 & & & & & -0.253 \\
\hline & $(0.64)$ & & & & & $(1.58)$ \\
\hline \multirow[t]{2}{*}{ spatial lag, contiguity-weighted } & & $0.232 * * *$ & & & & 0.287 \\
\hline & & $(2.70)$ & & & & $(1.56)$ \\
\hline \multirow[t]{2}{*}{ spatial lag, trade-weighted } & & & 0.197 & & & -0.007 \\
\hline & & & $(1.43)$ & & & $(0.02)$ \\
\hline \multirow[t]{2}{*}{ spatial lag, voting-weighted } & & & & $0.526^{* *}$ & & 0.533 \\
\hline & & & & $(2.26)$ & & $(1.48)$ \\
\hline \multirow[t]{2}{*}{ spatial lag, civilization-weighted } & & & & & 0.088 & -0.210 \\
\hline & & & & & $(1.22)$ & $(1.42)$ \\
\hline Method & GMM & GMM & GMM & GMM & GMM & GMM \\
\hline Number of observations & 807 & 974 & 983 & 983 & 983 & 801 \\
\hline Number of countries & 119 & 148 & 150 & 150 & 150 & 118 \\
\hline Number of instruments & 101 & 101 & 101 & 101 & 101 & 67 \\
\hline Arellano-Bond test ( $\mathrm{Pr}>\mathrm{z})$ & 0.27 & 0.42 & 0.19 & 0.20 & 0.25 & 0.40 \\
\hline Hansen test (Prob>chi2) & 0.50 & 0.26 & 0.29 & 0.15 & 0.13 & 0.28 \\
\hline
\end{tabular}

Notes: The dependent variable is the aggregate 3P index. Standard errors are clustered at the country level. A dummy for each year is included. Absolute z-statistics in parentheses; * $(* *, * * *)$ indicates significance at 10 (5, 1) percent level. 
Table 5: Anti-Trafficking Policies (prevention, prosecution, and protection), GMM, 2002-2009

\begin{tabular}{|c|c|c|c|c|c|c|c|c|}
\hline & $(1)$ & $(2)$ & (3) & (4) & (5) & (6) & (7) & (8) \\
\hline & \multicolumn{2}{|c|}{ Prevention } & \multicolumn{4}{|c|}{ Prosecution } & \multicolumn{2}{|c|}{ Protection } \\
\hline \multirow[t]{2}{*}{ dependent variable, t-1 } & $0.309 * * *$ & $0.301 * * *$ & $0.655^{* * *}$ & $0.644 * * *$ & $0.709 * * *$ & $0.708^{* * *}$ & $0.393 * * *$ & $0.389 * * *$ \\
\hline & $(4.92)$ & $(4.52)$ & $(10.96)$ & $(10.49)$ & $(16.49)$ & (18.68) & $(5.74)$ & $(5.51)$ \\
\hline \multirow[t]{2}{*}{ dependent variable, t-2 } & & & & & $0.182^{* * *}$ & $0.194^{* * *}$ & & \\
\hline & & & & & $(3.86)$ & $(4.52)$ & & \\
\hline \multirow[t]{2}{*}{ control of corruption } & $0.271^{* * *}$ & $0.213^{* * *}$ & -0.024 & 0.059 & -0.030 & 0.002 & $0.205^{* *}$ & $0.215^{* * *}$ \\
\hline & (3.13) & (3.87) & $(0.36)$ & (1.63) & (0.69) & $(0.05)$ & $(2.55)$ & $(4.45)$ \\
\hline \multirow[t]{2}{*}{ democracy } & $0.022 * * *$ & $0.029 * * *$ & $0.018^{* *}$ & $0.021 * *$ & 0.004 & 0.005 & $0.031^{* * *}$ & $0.038 * * *$ \\
\hline & $(2.71)$ & $(2.75)$ & $(2.00)$ & $(2.24)$ & $(0.72)$ & $(0.97)$ & $(3.82)$ & $(4.58)$ \\
\hline \multirow[t]{2}{*}{ women legislators (percent) } & 0.004 & 0.004 & 0.002 & -0.001 & -0.001 & -0.002 & $0.010 * *$ & $0.009 * *$ \\
\hline & $(1.07)$ & $(0.70)$ & $(0.49)$ & $(0.21)$ & $(0.45)$ & $(0.90)$ & $(2.20)$ & $(2.23)$ \\
\hline \multirow[t]{2}{*}{ women economic rights } & $0.099 * *$ & $0.102 * *$ & $0.111 * *$ & $0.109 * *$ & $0.057^{*}$ & $0.055^{*}$ & -0.014 & -0.028 \\
\hline & $(2.35)$ & $(2.16)$ & $(2.47)$ & $(2.37)$ & $(1.67)$ & $(1.67)$ & $(0.31)$ & $(0.57)$ \\
\hline international regime membership & 0.055 & & -0.004 & & 0.043 & & 0.037 & \\
\hline \multirow[t]{2}{*}{ (log) GDP p.c. } & -0.047 & & 0.046 & & 0.016 & & 0.013 & \\
\hline & $(1.03)$ & & $(1.00)$ & & $(0.49)$ & & $(0.28)$ & \\
\hline \multirow[t]{2}{*}{ US aid (percent of GDP) } & -0.006 & & -0.004 & & 0.002 & & -0.002 & \\
\hline & $(1.15)$ & & $(0.43)$ & & $(0.64)$ & & $(0.16)$ & \\
\hline Method & GMM & GMM & GMM & GMM & GMM & GMM & GMM & GMM \\
\hline Number of observations & 946 & 986 & 946 & 987 & 874 & 910 & 945 & 986 \\
\hline Number of countries & 145 & 150 & 145 & 150 & 143 & 147 & 145 & 150 \\
\hline Number of instruments & 60 & 57 & 60 & 57 & 64 & 61 & 60 & 57 \\
\hline Arellano-Bond test ( $\mathrm{Pr}>\mathrm{z})$ & 0.26 & 0.28 & 0.05 & 0.02 & 0.99 & 0.65 & 0.59 & 0.51 \\
\hline Hansen test (Prob>chi2) & 0.33 & 0.31 & 0.31 & 0.16 & 0.60 & 0.52 & 0.09 & 0.05 \\
\hline
\end{tabular}

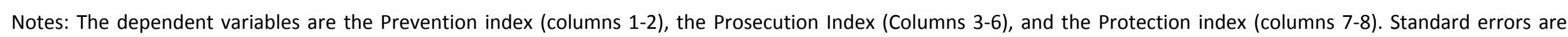
clustered at the country level. A dummy for each year is included. Absolute $z$-statistics in parentheses; $*(* *, * *)$ indicates significance at $10(5,1)$ percent level. 
Table 6: Anti-Trafficking Policies (Prevention and Protection) with spatial lags, GMM, 2002-2009

\begin{tabular}{|c|c|c|c|c|c|c|c|c|c|c|c|c|}
\hline & (1) & (2) & (3) & (4) & (5) & (6) & (7) & (8) & (9) & (10) & (11) & (12) \\
\hline & \multicolumn{6}{|c|}{ Prevention } & \multicolumn{6}{|c|}{ Protection } \\
\hline \multirow[t]{2}{*}{ dependent variable, $\mathrm{t}-1$} & $0.330 * * *$ & $0.335^{* * *}$ & $0.353^{* * *}$ & $0.343^{* * *}$ & $0.384 * * *$ & $0.352^{* * *}$ & $0.435^{* * *}$ & $0.431^{* * *}$ & $0.402^{* * *}$ & $0.475^{* * *}$ & $0.462^{* * *}$ & $0.386^{* * *}$ \\
\hline & $(4.99)$ & $(6.22)$ & $(5.86)$ & $(6.26)$ & $(6.06)$ & $(5.20)$ & $(7.00)$ & $(6.80)$ & $(6.44)$ & $(8.61)$ & $(7.15)$ & $(4.87)$ \\
\hline \multirow[t]{2}{*}{ control of corruption } & $0.233^{* * *}$ & $0.213^{* * *}$ & $0.213^{* * *}$ & $0.161^{* * *}$ & $0.186^{* * *}$ & $0.236^{* * *}$ & $0.217^{* * *}$ & $0.177^{* * *}$ & $0.199 * * *$ & $0.107 * *$ & $0.155^{* * *}$ & $0.202^{* * *}$ \\
\hline & $(2.88)$ & $(4.08)$ & $(4.09)$ & $(3.28)$ & $(3.76)$ & $(2.70)$ & $(3.41)$ & $(4.23)$ & $(4.39)$ & $(2.40)$ & $(4.06)$ & $(2.65)$ \\
\hline \multirow[t]{2}{*}{ democracy } & $0.025^{* *}$ & $0.022^{* *}$ & $0.028 * * *$ & $0.021^{* *}$ & $0.019 * *$ & 0.018 & $0.035^{* * *}$ & $0.033^{* * *}$ & $0.035^{* * *}$ & $0.023 * * *$ & $0.033^{* * *}$ & $0.023 * *$ \\
\hline & $(2.42)$ & $(2.46)$ & $(2.99)$ & $(2.41)$ & $(2.38)$ & $(1.41)$ & $(3.74)$ & $(4.54)$ & $(4.66)$ & $(3.06)$ & $(4.46)$ & $(2.08)$ \\
\hline \multirow[t]{2}{*}{ women legislators (percent) } & -0.002 & -0.002 & 0.002 & 0.002 & 0.003 & -0.003 & 0.003 & $0.009^{*}$ & $0.008^{*}$ & $0.008^{*}$ & 0.006 & 0.008 \\
\hline & $(0.56)$ & $(0.38)$ & $(0.39)$ & $(0.36)$ & $(0.51)$ & $(0.57)$ & $(0.83)$ & $(1.88)$ & $(1.69)$ & $(1.86)$ & $(1.42)$ & $(1.47)$ \\
\hline \multirow[t]{2}{*}{ women economic rights } & 0.081 & $0.095^{* *}$ & $0.089 * *$ & $0.099 * *$ & 0.074 & $0.097^{*}$ & 0.020 & 0.032 & -0.012 & 0.002 & -0.009 & 0.055 \\
\hline & $(1.54)$ & $(2.23)$ & $(2.04)$ & $(2.12)$ & $(1.48)$ & $(1.79)$ & $(0.36)$ & $(0.68)$ & $(0.24)$ & $(0.04)$ & $(0.18)$ & $(0.82)$ \\
\hline \multirow[t]{2}{*}{ spatial lag, traffic link-weighted } & -0.101 & & & & & -0.200 & -0.052 & & & & & -0.166 \\
\hline & $(1.03)$ & & & & & $(1.32)$ & $(0.48)$ & & & & & $(1.08)$ \\
\hline \multirow[t]{2}{*}{ spatial lag, contiguity-weighted } & & $0.168 *$ & & & & 0.133 & & 0.016 & & & & -0.030 \\
\hline & & $(1.91)$ & & & & $(1.08)$ & & $(0.16)$ & & & & $(0.22)$ \\
\hline \multirow[t]{2}{*}{ spatial lag, trade-weighted } & & & -0.030 & & & -0.333 & & & 0.079 & & & 0.211 \\
\hline & & & $(0.17)$ & & & $(1.11)$ & & & $(0.61)$ & & & $(0.93)$ \\
\hline \multirow[t]{2}{*}{ spatial lag, voting-weighted } & & & & $0.843^{* *}$ & & $1.317^{*}$ & & & & $0.957^{* * *}$ & & $1.214^{* *}$ \\
\hline & & & & $(2.01)$ & & $(1.91)$ & & & & $(2.83)$ & & $(2.29)$ \\
\hline \multirow[t]{2}{*}{ spatial lag, civilization-weighted } & & & & & $0.243^{* *}$ & -0.062 & & & & & 0.196 & -0.255 \\
\hline & & & & & $(2.06)$ & $(0.28)$ & & & & & $(1.47)$ & $(1.07)$ \\
\hline Method & GMM & GMM & GMM & GMM & GMM & GMM & GMM & GMM & GMM & GMM & GMM & GMM \\
\hline Number of observations & 810 & 977 & 986 & 986 & 986 & 804 & 810 & 977 & 986 & 986 & 986 & 804 \\
\hline Number of countries & 119 & 148 & 150 & 150 & 150 & 118 & 119 & 148 & 150 & 150 & 150 & 118 \\
\hline Number of instruments & 101 & 101 & 101 & 101 & 101 & 67 & 101 & 101 & 101 & 101 & 101 & 67 \\
\hline Arellano-Bond test ( $\mathrm{Pr}>\mathrm{z})$ & 0.39 & 0.32 & 0.39 & 0.39 & 0.41 & 0.39 & 0.45 & 0.45 & 0.47 & 0.32 & 0.43 & 0.45 \\
\hline Hansen test (Prob>chi2) & 0.44 & 0.85 & 0.11 & 0.19 & 0.06 & 0.35 & 0.34 & 0.41 & 0.14 & 0.19 & 0.21 & 0.26 \\
\hline
\end{tabular}

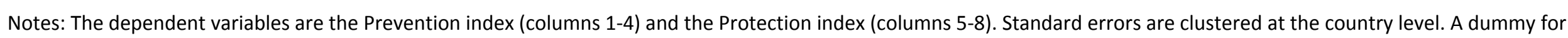
each year is included. Absolute $z$-statistics in parentheses; * $(* *, * * *)$ indicates significance at $10(5,1)$ percent level. 
Table 7: Anti-Trafficking Policies (Prosecution) with spatial lags, GMM, 2002-2009

\begin{tabular}{|c|c|c|c|c|c|c|c|c|c|c|c|c|}
\hline & (1) & (2) & (3) & (4) & (5) & (6) & (7) & (8) & (9) & (10) & (11) & (12) \\
\hline & \multicolumn{12}{|c|}{ Prosecution } \\
\hline dependent variable, t-1 & $\begin{array}{l}0.640^{* * *} \\
(10.88)\end{array}$ & $\begin{array}{l}0.649^{* * *} \\
(10.15)\end{array}$ & $\begin{array}{l}0.671^{* * *} \\
(12.63)\end{array}$ & $\begin{array}{l}0.688^{* * *} \\
(11.38)\end{array}$ & $\begin{array}{l}0.650^{* * *} \\
(11.06)\end{array}$ & $\begin{array}{l}0.525^{* * *} \\
(7.69)\end{array}$ & $\begin{array}{l}0.666^{* * *} \\
(15.09)\end{array}$ & $\begin{array}{l}0.650^{* * *} \\
(13.79)\end{array}$ & $\begin{array}{l}0.676^{* * *} \\
(15.49)\end{array}$ & $\begin{array}{l}0.674^{* * *} \\
(17.15)\end{array}$ & $\begin{array}{l}0.623^{* * *} \\
(13.18)\end{array}$ & $\begin{array}{l}0.613^{* * *} \\
(9.23)\end{array}$ \\
\hline dependent variable, $\mathrm{t}-2$ & & & & & & & $\begin{array}{l}0.238^{* * *} \\
(4.71)\end{array}$ & $\begin{array}{l}0.151^{* * *} \\
(2.86)\end{array}$ & $\begin{array}{l}0.165^{* * *} \\
(2.90)\end{array}$ & $\begin{array}{l}0.200^{* * *} \\
(3.92)\end{array}$ & $\begin{array}{l}0.190^{* * *} \\
(3.60)\end{array}$ & $\begin{array}{l}0.144^{* * *} \\
(2.72)\end{array}$ \\
\hline control of corruption & $\begin{array}{r}0.065 \\
(1.33)\end{array}$ & $\begin{array}{r}0.062 \\
(1.58)\end{array}$ & $\begin{array}{r}0.004 \\
(0.12)\end{array}$ & $\begin{array}{r}0.031 \\
(0.90)\end{array}$ & $\begin{array}{r}0.056 \\
(1.55)\end{array}$ & $\begin{array}{l}0.092^{*} \\
(1.70)\end{array}$ & $\begin{array}{c}0.022 \\
(0.50)\end{array}$ & $\begin{array}{l}-0.003 \\
(0.09)\end{array}$ & $\begin{array}{l}-0.010 \\
(0.29)\end{array}$ & $\begin{array}{l}-0.017 \\
(0.44)\end{array}$ & $\begin{array}{l}0.013 \\
(0.46)\end{array}$ & $\begin{array}{c}0.084 \\
(1.14)\end{array}$ \\
\hline democracy & $\begin{array}{l}0.008 \\
(0.86)\end{array}$ & $\begin{array}{l}0.000 \\
(0.03)\end{array}$ & $\begin{array}{l}0.012 \\
(1.48)\end{array}$ & $\begin{array}{l}0.014 \\
(1.56)\end{array}$ & $\begin{array}{l}0.015^{*} \\
(1.81)\end{array}$ & $\begin{array}{l}0.013 \\
(1.13)\end{array}$ & $\begin{array}{r}0.007 \\
(1.46)\end{array}$ & $\begin{array}{l}-0.003 \\
(0.51)\end{array}$ & $\begin{array}{l}0.004 \\
(0.68)\end{array}$ & $\begin{array}{l}-0.002 \\
(0.29)\end{array}$ & $\begin{array}{l}0.004 \\
(0.73)\end{array}$ & $\begin{array}{l}0.003 \\
(0.31)\end{array}$ \\
\hline women legislators (percent) & $\begin{array}{l}-0.002 \\
(0.50)\end{array}$ & $\begin{array}{l}-0.001 \\
(0.25)\end{array}$ & $\begin{array}{l}0.002 \\
(0.60)\end{array}$ & $\begin{array}{l}-0.002 \\
(0.52)\end{array}$ & $\begin{array}{r}0.001 \\
(0.33)\end{array}$ & $\begin{array}{l}-0.007^{*} \\
(1.65)\end{array}$ & $\begin{array}{l}-0.004^{*} \\
(1.72)\end{array}$ & $\begin{array}{l}-0.004 \\
(1.49)\end{array}$ & $\begin{array}{l}-0.002 \\
(1.01)\end{array}$ & $\begin{array}{l}-0.002 \\
(1.09)\end{array}$ & $\begin{array}{l}-0.002 \\
(0.83)\end{array}$ & $\begin{array}{l}-0.010^{* *} \\
(2.40)\end{array}$ \\
\hline women economic rights & $\begin{array}{r}0.074 \\
(1.49)\end{array}$ & $\begin{array}{r}0.056 \\
(1.16)\end{array}$ & $\begin{array}{r}0.051 \\
(1.21)\end{array}$ & $\begin{array}{l}0.080^{*} \\
(1.65)\end{array}$ & $\begin{array}{r}0.035 \\
(0.71)\end{array}$ & $\begin{array}{l}0.097^{*} \\
(1.86)\end{array}$ & $\begin{array}{l}0.095^{*} \\
(1.91)\end{array}$ & $\begin{array}{l}0.020 \\
(0.44)\end{array}$ & $\begin{array}{r}0.051 \\
(1.25)\end{array}$ & $\begin{array}{l}0.062 \\
(1.46)\end{array}$ & $\begin{array}{r}0.053 \\
(1.29)\end{array}$ & $\begin{array}{l}0.114^{* *} \\
(2.17)\end{array}$ \\
\hline spatial lag, traffic link-weighted & $\begin{array}{l}0.220^{* *} \\
(2.17)\end{array}$ & & & & & $\begin{array}{l}-0.214 \\
(1.20)\end{array}$ & $\begin{array}{l}-0.181 \\
(0.99)\end{array}$ & & & & & $\begin{array}{l}-0.575^{* * *} \\
(2.92)\end{array}$ \\
\hline spatial lag, contiguity-weighted & & $\begin{array}{l}0.300^{* * *} \\
(3.43)\end{array}$ & & & & $\begin{array}{l}0.264^{* *} \\
(2.41)\end{array}$ & & $\begin{array}{l}0.296^{* * *} \\
(4.13)\end{array}$ & & & & $\begin{array}{l}0.456^{* * *} \\
(3.05)\end{array}$ \\
\hline spatial lag, trade-weighted & & & $\begin{array}{l}0.571^{* * *} \\
(4.17)\end{array}$ & & & $\begin{array}{l}-0.157 \\
(0.63)\end{array}$ & & & $\begin{array}{l}0.376^{* *} \\
(2.24)\end{array}$ & & & $\begin{array}{l}-0.291 \\
(1.24)\end{array}$ \\
\hline spatial lag, voting-weighted & & & & $\begin{array}{r}0.449 \\
(1.53)\end{array}$ & & $\begin{array}{l}0.202 \\
(0.43)\end{array}$ & & & & $\begin{array}{r}0.461 \\
(1.05)\end{array}$ & & $\begin{array}{l}0.152 \\
(0.27)\end{array}$ \\
\hline spatial lag, civilization-weighted & & & & & $\begin{array}{l}0.202^{* * *} \\
(3.00)\end{array}$ & $\begin{array}{r}0.110 \\
(1.04)\end{array}$ & & & & & $\begin{array}{l}0.173^{* *} \\
(2.37)\end{array}$ & $\begin{array}{l}0.008 \\
(0.06)\end{array}$ \\
\hline Method & GMM & GMM & GMM & GMM & GMM & GMM & GMM & GMM & GMM & GMM & GMM & GMM \\
\hline Number of observations & 811 & 978 & 987 & 987 & 987 & 805 & 757 & 903 & 910 & 910 & 910 & 752 \\
\hline Number of countries & 119 & 148 & 150 & 150 & 150 & 118 & 117 & 145 & 147 & 147 & 147 & 116 \\
\hline Number of instruments & 101 & 101 & 101 & 101 & 101 & 67 & 31 & 31 & 31 & 31 & 31 & 67 \\
\hline Arellano-Bond test ( $\mathrm{Pr}>\mathrm{z})$ & 0.04 & 0.04 & 0.02 & 0.02 & 0.03 & 0.05 & 0.62 & 0.61 & 0.40 & 0.71 & 0.76 & 0.86 \\
\hline Hansen test (Prob>chi2) & 0.15 & 0.19 & 0.20 & 0.18 & 0.02 & 0.51 & 0.67 & 0.81 & 0.95 & 0.97 & 0.81 & 0.89 \\
\hline
\end{tabular}

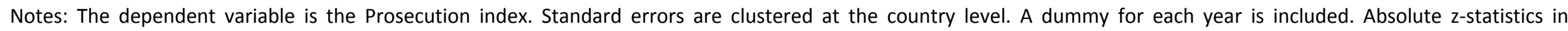
parentheses; $*(* *, * *)$ indicates significance at $10(5,1)$ percent level. 
Table 8: Regional jackknife analysis for aggregate and prevention policies.

\begin{tabular}{|c|c|c|c|c|c|c|c|}
\hline & $\begin{array}{c}(1) \\
\text { Western/OECD }\end{array}$ & $\begin{array}{c}\text { (2) } \\
\text { East Asia }\end{array}$ & $\begin{array}{c}\text { (3) } \\
\text { Eastern } \\
\text { Europe/Central }\end{array}$ & $\begin{array}{c}\text { (4) } \\
\text { Latin } \\
\text { America/Carib }\end{array}$ & $\begin{array}{c}(5) \\
\text { Middle } \\
\text { East/North }\end{array}$ & $\begin{array}{c}\text { (6) } \\
\text { South Asia }\end{array}$ & $\begin{array}{c}\text { (7) } \\
\text { Sub-Saharan } \\
\text { Africa }\end{array}$ \\
\hline \multicolumn{8}{|l|}{ P3 } \\
\hline traffic link-weighted & $\begin{array}{r}0.034 \\
(0.38)\end{array}$ & $\begin{array}{r}0.053 \\
(0.64)\end{array}$ & $\begin{array}{r}0.020 \\
(0.23)\end{array}$ & $\begin{array}{r}0.122 \\
(1.56)\end{array}$ & $\begin{array}{r}0.135 \\
(1.53)\end{array}$ & $\begin{array}{r}0.049 \\
(0.65)\end{array}$ & $\begin{array}{l}-0.322^{*} \\
(1.85)\end{array}$ \\
\hline contiguity-weighted & $\begin{array}{l}0.243^{* * *} \\
(2.69)\end{array}$ & $\begin{array}{l}0.280^{* * *} \\
(2.95)\end{array}$ & $\begin{array}{l}0.143^{*} \\
(1.71)\end{array}$ & $\begin{array}{l}0.260^{* * *} \\
(3.04)\end{array}$ & $\begin{array}{l}0.204^{* *} \\
(2.29)\end{array}$ & $\begin{array}{l}0.216^{* *} \\
(2.43)\end{array}$ & $\begin{array}{l}0.172^{* *} \\
(1.97)\end{array}$ \\
\hline trade-weighted & $\begin{array}{l}0.239 * * \\
(2.07)\end{array}$ & $\begin{array}{r}0.150 \\
(1.13)\end{array}$ & $\begin{array}{r}0.142 \\
(1.17)\end{array}$ & $\begin{array}{l}0.310^{*} \\
(1.88)\end{array}$ & $\begin{array}{c}0.252 \\
(1.46)\end{array}$ & $\begin{array}{r}0.181 \\
(1.29)\end{array}$ & $\begin{array}{l}0.015 \\
(0.12)\end{array}$ \\
\hline voting-weighted & $\begin{array}{l}0.531^{* *} \\
(2.00)\end{array}$ & $\begin{array}{l}0.568^{* *} \\
(2.46)\end{array}$ & $\begin{array}{l}0.608^{* *} \\
(2.28)\end{array}$ & $\begin{array}{l}0.484^{* *} \\
(2.17)\end{array}$ & $\begin{array}{l}0.426^{*} \\
(1.76)\end{array}$ & $\begin{array}{l}0.525^{* *} \\
(2.29)\end{array}$ & $\begin{array}{l}0.403^{*} \\
(1.69)\end{array}$ \\
\hline civilization-weighted & $\begin{array}{l}0.204^{* * *} \\
(2.73)\end{array}$ & $\begin{array}{r}0.103 \\
(1.40)\end{array}$ & $\begin{array}{r}0.017 \\
(0.18)\end{array}$ & $\begin{array}{r}0.069 \\
(1.02)\end{array}$ & $\begin{array}{r}0.082 \\
(1.09)\end{array}$ & $\begin{array}{r}0.080 \\
(0.98)\end{array}$ & $\begin{array}{l}0.074 \\
(1.25)\end{array}$ \\
\hline Prevention & & & & & & & \\
\hline traffic link-weighted & $\begin{array}{l}-0.092 \\
(0.81)\end{array}$ & $\begin{array}{l}-0.106 \\
(0.95)\end{array}$ & $\begin{array}{l}-0.112 \\
(1.22)\end{array}$ & $\begin{array}{r}0.033 \\
(0.34)\end{array}$ & $\begin{array}{l}-0.057 \\
(0.51)\end{array}$ & $\begin{array}{l}-0.156 \\
(1.55)\end{array}$ & $\begin{array}{l}-0.171 \\
(1.02)\end{array}$ \\
\hline contiguity-weighted & $\begin{array}{l}0.177^{*} \\
(1.66)\end{array}$ & $\begin{array}{l}0.184^{*} \\
(1.77)\end{array}$ & $\begin{array}{r}0.119 \\
(1.32)\end{array}$ & $\begin{array}{l}0.188^{* *} \\
(2.07)\end{array}$ & $\begin{array}{r}0.130 \\
(1.40)\end{array}$ & $\begin{array}{l}0.177^{*} \\
(1.83)\end{array}$ & $\begin{array}{r}0.126 \\
(1.54)\end{array}$ \\
\hline trade-weighted & $\begin{array}{l}-0.092 \\
(0.56)\end{array}$ & $\begin{array}{l}-0.017 \\
(0.10)\end{array}$ & $\begin{array}{l}-0.160 \\
(0.99)\end{array}$ & $\begin{array}{r}0.012 \\
(0.07)\end{array}$ & $\begin{array}{l}0.082 \\
(0.39)\end{array}$ & $\begin{array}{l}-0.082 \\
(0.44)\end{array}$ & $\begin{array}{r}0.056 \\
(0.31)\end{array}$ \\
\hline voting-weighted & $\begin{array}{l}0.985^{*} \\
(1.71)\end{array}$ & $\begin{array}{l}1.074^{* *} \\
(2.45)\end{array}$ & $\begin{array}{l}1.092^{* *} \\
(2.25)\end{array}$ & $\begin{array}{r}0.656 \\
(1.47)\end{array}$ & $\begin{array}{r}0.650 \\
(1.54)\end{array}$ & $\begin{array}{l}0.681 \\
(1.54)\end{array}$ & $\begin{array}{l}0.939^{* * *} \\
(2.70)\end{array}$ \\
\hline civilization-weighted & $\begin{array}{l}0.295^{* * *} \\
(2.60)\end{array}$ & $\begin{array}{l}0.223^{*} \\
(1.73)\end{array}$ & $\begin{array}{l}0.229^{*} \\
(1.86)\end{array}$ & $\begin{array}{l}0.219^{*} \\
(1.80)\end{array}$ & $\begin{array}{r}0.135 \\
(1.22)\end{array}$ & $\begin{array}{l}0.311^{* *} \\
(2.55)\end{array}$ & $\begin{array}{l}0.233^{* *} \\
(2.17)\end{array}$ \\
\hline
\end{tabular}

Notes: Reports the same regressions as in table 4 for 3P and column (1)-(5) of table 6 for prevention, respectively, excluding one region at the time. 
Table 9: Regional jackknife analysis for protection and prosecution policies.

\begin{tabular}{|c|c|c|c|c|c|c|c|}
\hline & $\begin{array}{c}(1) \\
\text { Western/OECD }\end{array}$ & $\begin{array}{c}(2) \\
\text { East Asia }\end{array}$ & $\begin{array}{c}\text { (3) } \\
\text { Eastern } \\
\text { Europe/Central }\end{array}$ & $\begin{array}{c}\text { (4) } \\
\text { Latin } \\
\text { America/Carib }\end{array}$ & $\begin{array}{c}\text { (5) } \\
\text { Middle } \\
\text { East/North }\end{array}$ & $\begin{array}{c}\text { (6) } \\
\text { South Asia }\end{array}$ & $\begin{array}{c}\text { (7) } \\
\text { Sub-Saharan } \\
\text { Africa }\end{array}$ \\
\hline \multicolumn{8}{|l|}{ Protection } \\
\hline traffic link-weighted & $\begin{array}{l}-0.043 \\
(0.30)\end{array}$ & $\begin{array}{l}-0.085 \\
(0.80)\end{array}$ & $\begin{array}{l}-0.090 \\
(0.87)\end{array}$ & $\begin{array}{l}-0.046 \\
(0.36)\end{array}$ & $\begin{array}{r}0.022 \\
(0.22)\end{array}$ & $\begin{array}{l}-0.057 \\
(0.53)\end{array}$ & $\begin{array}{r}0.014 \\
(0.11)\end{array}$ \\
\hline contiguity-weighted & $\begin{array}{l}0.101 \\
(0.91)\end{array}$ & $\begin{array}{l}-0.008 \\
(0.09)\end{array}$ & $\begin{array}{l}-0.048 \\
(0.48)\end{array}$ & $\begin{array}{l}0.073 \\
(0.71)\end{array}$ & $\begin{array}{l}0.046 \\
(0.43)\end{array}$ & $\begin{array}{l}0.018 \\
(0.17)\end{array}$ & $\begin{array}{l}0.045 \\
(0.49)\end{array}$ \\
\hline trade-weighted & $\begin{array}{r}0.041 \\
(0.29)\end{array}$ & $\begin{array}{r}0.044 \\
(0.31)\end{array}$ & $\begin{array}{r}0.043 \\
(0.34)\end{array}$ & $\begin{array}{r}0.012 \\
(0.09)\end{array}$ & $\begin{array}{r}0.093 \\
(0.66)\end{array}$ & $\begin{array}{r}0.050 \\
(0.37)\end{array}$ & $\begin{array}{l}-0.018 \\
(0.14)\end{array}$ \\
\hline voting-weighted & $\begin{array}{l}1.050^{* * *} \\
(2.71)\end{array}$ & $\begin{array}{l}1.052^{* * *} \\
(3.00)\end{array}$ & $\begin{array}{l}1.098^{* * *} \\
(3.11)\end{array}$ & $\begin{array}{l}0.831^{* * *} \\
(2.65)\end{array}$ & $\begin{array}{l}0.811^{* *} \\
(2.38)\end{array}$ & $\begin{array}{l}0.885^{* *} \\
(2.51)\end{array}$ & $\begin{array}{l}0.935^{* * *} \\
(2.72)\end{array}$ \\
\hline civilization-weighted & $\begin{array}{l}0.243^{* *} \\
(2.09)\end{array}$ & $\begin{array}{r}0.161 \\
(1.22)\end{array}$ & $\begin{array}{l}0.309^{* *} \\
(1.99)\end{array}$ & $\begin{array}{r}0.146 \\
(1.02)\end{array}$ & $\begin{array}{l}0.111 \\
(0.87)\end{array}$ & $\begin{array}{l}0.247^{*} \\
(1.75)\end{array}$ & $\begin{array}{r}0.067 \\
(0.58)\end{array}$ \\
\hline Prosecution & & & & & & & \\
\hline traffic link-weighted & $\begin{array}{l}-0.005 \\
(0.03)\end{array}$ & $\begin{array}{l}-0.219 \\
(1.12)\end{array}$ & $\begin{array}{l}-0.424^{* *} \\
(2.25)\end{array}$ & $\begin{array}{l}-0.218 \\
(1.09)\end{array}$ & $\begin{array}{l}0.007 \\
(0.05)\end{array}$ & $\begin{array}{l}-0.137 \\
(0.79)\end{array}$ & $\begin{array}{l}-0.799 * * \\
(2.02)\end{array}$ \\
\hline contiguity-weighted & $\begin{array}{l}0.231^{* * *} \\
(2.93)\end{array}$ & $\begin{array}{l}0.338^{* * *} \\
(4.27)\end{array}$ & $\begin{array}{l}0.226^{* * *} \\
(2.68)\end{array}$ & $\begin{array}{l}0.372^{* * *} \\
(4.33)\end{array}$ & $\begin{array}{l}0.311^{* * *} \\
(4.35)\end{array}$ & $\begin{array}{l}0.288^{* * *} \\
(3.95)\end{array}$ & $\begin{array}{l}0.371^{* * *} \\
(3.74)\end{array}$ \\
\hline trade-weighted & $\begin{array}{l}0.324^{* *} \\
(1.99)\end{array}$ & $\begin{array}{l}0.403^{* *} \\
(2.38)\end{array}$ & $\begin{array}{r}0.250 \\
(1.30)\end{array}$ & $\begin{array}{l}0.360^{* *} \\
(2.09)\end{array}$ & $\begin{array}{l}0.427^{* *} \\
(2.34)\end{array}$ & $\begin{array}{l}0.386^{* *} \\
(2.20)\end{array}$ & $\begin{array}{l}0.462^{* *} \\
(2.10)\end{array}$ \\
\hline voting-weighted & $\begin{array}{l}-0.000 \\
(0.00)\end{array}$ & $\begin{array}{r}0.561 \\
(1.17)\end{array}$ & $\begin{array}{r}0.351 \\
(0.65)\end{array}$ & $\begin{array}{l}0.398 \\
(0.91)\end{array}$ & $\begin{array}{r}0.518 \\
(1.13)\end{array}$ & $\begin{array}{r}0.478 \\
(1.07)\end{array}$ & $\begin{array}{r}0.694 \\
(1.51)\end{array}$ \\
\hline civilization-weighted & $\begin{array}{r}0.115 \\
(1.36)\end{array}$ & $\begin{array}{l}0.202^{* * *} \\
(2.77)\end{array}$ & $\begin{array}{r}0.099 \\
(0.94)\end{array}$ & $\begin{array}{l}0.170^{* *} \\
(2.11)\end{array}$ & $\begin{array}{l}0.196^{* * *} \\
(2.70)\end{array}$ & $\begin{array}{l}0.186^{* *} \\
(2.21)\end{array}$ & $\begin{array}{l}0.232^{* * *} \\
(3.00)\end{array}$ \\
\hline
\end{tabular}

Notes: Reports the same regressions as in column (6)-(10) of table 6 for protection and column (6)-(10) of table 7 for prosecution, respectively, excluding one region at the time. 
Table 10: Extreme Bounds Analysis, GMM, 2002-2009

\begin{tabular}{|c|c|c|c|c|c|c|c|c|c|}
\hline Variable & Avg. Beta & Avg.Std.Err & \%Sign. & CDF-U & Variable & Avg. Beta & Avg.Std.Err & \%Sign. & CDF-U \\
\hline \multicolumn{5}{|l|}{ P3 } & \multicolumn{5}{|c|}{ Protection } \\
\hline dependent variable, t-1 & 0.51 & 0.09 & 1.00 & 1.00 & dependent variable, t-1 & 0.32 & 0.09 & 0.99 & 0.99 \\
\hline control of corruption & 0.15 & 0.23 & 0.29 & 0.74 & Corruption & 0.23 & 0.12 & 0.71 & 0.90 \\
\hline democracy & 0.05 & 0.02 & 0.71 & 0.95 & Democracy & 0.02 & 0.01 & 0.73 & 0.93 \\
\hline women legislators (percent) & 0.00 & 0.01 & 0.00 & 0.52 & Women in parliament & 0.00 & 0.01 & 0.01 & 0.70 \\
\hline women economic rights & 0.29 & 0.13 & 0.91 & 0.98 & Women economic rights & 0.04 & 0.07 & 0.00 & 0.72 \\
\hline traffic link-weighted & 0.02 & 0.12 & 0.09 & 0.60 & traffic link-weighted & -0.12 & 0.15 & 0.09 & 0.77 \\
\hline contiguity-weighted & 0.21 & 0.11 & 0.78 & 0.95 & contiguity-weighted & -0.06 & 0.16 & 0.00 & 0.63 \\
\hline trade-weighted & 0.18 & 0.19 & 0.21 & 0.81 & trade-weighted & -0.05 & 0.21 & 0.01 & 0.56 \\
\hline voting-weighted & 0.37 & 0.32 & 0.41 & 0.84 & voting-weighted & 0.83 & 0.44 & 0.64 & 0.95 \\
\hline civilization-weighted & 0.15 & 0.12 & 0.26 & 0.83 & civilization-weighted & 0.23 & 0.22 & 0.32 & 0.80 \\
\hline \multicolumn{5}{|l|}{ Prevention } & \multicolumn{5}{|c|}{ Prosecution } \\
\hline dependent variable, t-1 & 0.32 & 0.07 & 1.00 & 1.00 & dependent variable, t-1 & 0.69 & 0.06 & 1.00 & 1.00 \\
\hline Corruption & 0.16 & 0.12 & 0.48 & 0.89 & Dependent variable, $\mathrm{t}-2$ & 0.19 & 0.07 & 0.91 & 0.99 \\
\hline Democracy & 0.02 & 0.01 & 0.54 & 0.94 & Corruption & -0.11 & 0.10 & 0.33 & 0.79 \\
\hline Women in parliament & 0.00 & 0.01 & 0.00 & 0.65 & Democracy & 0.01 & 0.01 & 0.08 & 0.71 \\
\hline \multirow[t]{2}{*}{ Women economic rights } & 0.13 & 0.06 & 0.84 & 0.97 & Women in parliament & 0.00 & 0.00 & 0.26 & 0.86 \\
\hline & & & & & Women economic rights & 0.10 & 0.07 & 0.45 & 0.92 \\
\hline traffic link-weighted & -0.10 & 0.13 & 0.12 & 0.72 & & & & & \\
\hline contiguity-weighted & 0.13 & 0.12 & 0.24 & 0.82 & traffic link-weighted & -0.14 & 0.24 & 0.11 & 0.68 \\
\hline trade-weighted & 0.03 & 0.21 & 0.02 & 0.53 & contiguity-weighted & 0.26 & 0.10 & 0.99 & 0.99 \\
\hline voting-weighted & 0.59 & 0.51 & 0.43 & 0.84 & trade-weighted & 0.32 & 0.28 & 0.51 & 0.89 \\
\hline \multirow[t]{2}{*}{ civilization-weighted } & 0.40 & 0.17 & 0.83 & 0.98 & voting-weighted & 0.72 & 0.53 & 0.18 & 0.86 \\
\hline & & & & & civilization-weighted & 0.11 & 0.10 & 0.37 & 0.81 \\
\hline
\end{tabular}

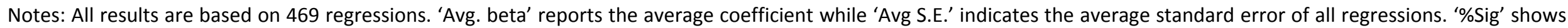

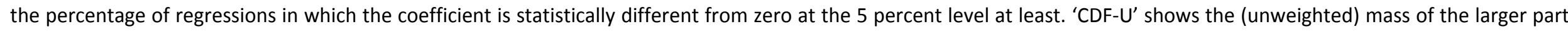
of the distribution of the estimated coefficients (i.e., the value is always greater or equal to 0.5 ). The criterion for a variable we consider as robust is a value of 0.9 or above. 


\section{Appendix A: Anti-trafficking Policy Index Coding Guideline}

(The full-version is available in the online appendix at www.human-trafficing-research.org)

\section{Prosecution}

\section{Coding Scheme}

In measuring government prosecution policy, our primary interests are: 1) whether the country has legislative and other measures to establish criminal offences for trafficking in persons, in line with the definition provided by the Anti-trafficking Protocol; and 2) whether such legislative and other measures are appropriately and effectively enforced.

\section{Score 5:}

The country has a legislative measure specifically prohibiting trafficking in persons and; the law is fully enforced in the form of investigations, prosecutions, convictions and punishment of such offenders. Generally, the country should maintain a stringent level of penalty (either more than five years imprisonment or punishment equivalent to other related crimes such as rape or labor exploitation).

\section{Score 4:}

The country has a legislative measure specifically prohibiting trafficking in persons; BUT the law is not fully enforced in the form of investigations, prosecutions, convictions and punishment of such offenders.

\section{Score 3:}

The country does NOT have a legislative measure specifically prohibiting trafficking in persons; but applies some other relevant laws (such as laws against rape, slavery, exploitation, abuse or human rights violation) to punish offenders of such crimes; and the law is fully or adequately enforced in the form of investigations, prosecutions, convictions and punishment of such offenders.

\section{Score 2:}

The country does NOT have a legislative measure specifically prohibiting trafficking in persons; BUT applies some other related law to punish offenders of such crimes; the law is not adequately enforced in the form of investigations, prosecutions, convictions and punishment of such offenders. If the country has a legislative measure specifically prohibiting trafficking in persons but does not enforce the law at all (or there is no evidence that the country has conducted prosecution or conviction of such offenders), it also receives score 2. 


\section{Score 1:}

The country does NOT have a legislative measure prohibiting trafficking in persons and no other law is applied; and there is no evidence of punishment for such a crime at all.

\section{Protection}

\section{Coding Scheme}

In measuring government protection policy, our primary interests are: whether the country protects the human rights of victims of trafficking; identifies them; and provides for the physical, psychological and social recovery of victims of trafficking by legislative and other measures.

\section{Score 5:}

The country does not punish victims of trafficking for acts related to the situations being trafficked; does not impose the self-identification of victims; and exerts STRONG efforts to give victims information on, and assistance for, relevant court and administrative proceedings, as well as support for the physical, psychological and social recovery of victims such as housing (shelter), medical assistance, job training, (temporal) residence permit, and other assistance for rehabilitation and repatriation.

\section{Score 4:}

The country does not punish victims of trafficking for acts related to the situations being trafficked; does not impose the self-identification of victims; and exerts MODERATE efforts to give victims information on, and assistance for, relevant court and administrative proceedings, as well as support for the physical, psychological and social recovery of victims such as housing (shelter), medical assistance, job training, (temporal) residence permit, and other assistance for rehabilitation and repatriation.

\section{Score 3:}

The country does not punish victims of trafficking for acts related to the situations being trafficked; does not impose the self-identification of victims; and exerts LIMITED efforts to give victims information on, and assistance for, relevant court and administrative proceedings, as well as support for the physical, psychological and social recovery of victims such as housing (shelter), medical assistance, job training, (temporal) residence permit, and other assistance for rehabilitation and repatriation. Or, if the country fails to ensure that victims of trafficking are never punished for acts related to the trafficking itself or the consequences of being trafficking BUT exerts STRONG/Moderate efforts in protecting victims, the country qualifies for score 3 . 


\section{Score 2:}

The country fails to ensure that victims of trafficking are punished for acts related to the trafficking itself or to the consequences of being trafficked; and there is limited assistance and support for court proceedings and the recovery of victims. Or, the country does not punish victims of trafficking in persons for acts related to the situations being trafficked; however, does not provide any assistance or support for recovery, rehabilitation and repatriation.

\section{Score 1:}

The country punishes victims of trafficking in persons for acts related to the situations being trafficked; and does not provide any assistance and support.

\section{Prevention}

\section{Coding Scheme}

In measuring government protection policy, our primary interests are; whether the country establishes and practices comprehensive policies, programs and other measures to prevent and combat trafficking in persons. ${ }^{32}$

\section{Score 5:}

The country demonstrates VERY STRONG efforts preventing trafficking in persons, such as implementing public and media campaigns for anti-trafficking awareness; training government and military officials (including peace keepers); facilitating information exchange among relevant authorities; monitoring borders, train stations, airports, etc.; adopting national action plans for combating trafficking in persons; promoting cooperation with NGOs and international organizations in the country; and facilitating bilateral and/or multilateral cooperation with other governments.

\section{Score 4:}

The country demonstrates STRONG efforts against trafficking in persons, such as implementing public and media campaigns for anti-trafficking awareness; training government and military officials (including peace keepers); facilitating information exchange among relevant authorities; monitoring borders, train stations, airports, etc.; adopting national action plans for combating trafficking in persons; promoting cooperation with NGOs and international organizations in the country; and facilitating bilateral and/or multilateral cooperation with other governments.

\footnotetext{
${ }^{32}$ In evaluating the preventive efforts of governments, we do not include broader developmental measures, such as promotion of education and poverty reduction, in order to distinguish governmental efforts specifically addressed at fighting human trafficking.
} 


\section{Score 3:}

The country demonstrates MODEST efforts against trafficking in persons, such as implementing public and media campaigns for anti-trafficking awareness; training government and military officials (including peace keepers); facilitating information exchange among relevant authorities; monitoring borders, train stations, airports, etc.; adopting national action plans for combating trafficking in persons; promoting cooperation with NGOs and international organizations in the country; and facilitating bilateral and/or multilateral cooperation with other governments.

\section{Score 2:}

The country demonstrates LIMITED efforts against trafficking in persons, such as implementing public and media campaigns for anti-trafficking awareness; training government and military officials (including peace keepers); facilitating information exchange among relevant authorities; monitoring borders, train stations, airports, etc.; adopting national action plans for combating trafficking in persons; promoting cooperation with NGOs and international organizations in the country; and facilitating bilateral and/or multilateral cooperation with other governments.

\section{Score 1:}

The country demonstrates NO efforts against trafficking in persons. 
Appendix B. Data Description and Sources

\section{Variable \\ Prosecution \\ Protection \\ Prevention \\ Aggregate 3Ps \\ Tier-ranking}

Control of Corruption

Democracy

Women Legislators

Women's Economic and Social Rights Workers' Rights

Intl. regime membership

US aid

(log) GDP pc

UNGA Voting

Bilateral Trade Flows

Contiguity dummy

Common Civilization dummy

Traffic-linkage

Rule of Law

Law and Order

KOF Globalization Index

Media Freedom

EU membership

Remittance

\section{Description}

Prosecution policy measure. Scale 5 (full compliance) to 1 (no compliance).

Protection policy measure. Scale 5 (full compliance) to 1 (no compliance).

Prevention policy measure. Scale 5 (full compliance) to 1 (no compliance).

Sum of prevention, protection and prosecution scores. Scale 15 to 3 .

Compliance with US anti-trafficking law. Scale 1 (full compliance) to 3 (no compliance).

Around -1.63 to 2.58, with higher values corresponding to better outcomes Measure of democracy. +10 (full democracy) to -10 (full autocracy). Share of female legislators in parliament.

Score 3 (nearly fully guaranteed) to score 0 (no rights).

Score 2 (fully granted) to 0 (severely restricted).

Code 1 if the country is a member of the

Anti-trafficking Protocol in a given year. Otherwise, 0.

Share of bilateral aid from the US (\% of GDP).

Per capita income in 2000 constant prices.

Bilateral similarities in voting behaviors on key votes in the UN General Assembly.

Amounts of bilateral trade flows between two countries.

Code 1 if two countries share a land border or are separated by less than 150 miles of sea distance; otherwise, 0 .

Code 1 if two countries share a common civilization (Western, Islamic, Africa, Latin American, Sinic or Hindu); otherwise 0. Severity of bilateral human trafficking flows in destination country from origin or transit countries: From 9 (high flows) to 0 (no flows).

Around -2.5 to 2.5 , with higher values corresponding to better outcomes.

Assessment on legal system and observance of low. Score 2 to 6 , with higher values corresponding to better outcomes.

Economic, social and political globalization. Score 1-100, with a higher value corresponding to higher globalization. Freedom of the Press Index . Score 0 (best) to 100 (worst).

Dummy variable. Code 1 if a country is a member of the EU in the year, otherwise, 0 . Inflows of remittance (\% of GDP).

\section{Source}

own calculations

own calculations

own calculations

own calculations

United States Department of State (2001-2010)

Kaufmann, Kraay and Mastruzzi (2009)

Polity IV data (Marshall and Jaggers, 2009)

World Bank Gender Statistics

http://data.worldbank.org/indicator/

Cingranelli-Richards Human Rights

Dataset (2008)

Cingranelli-Richards Human Rights

Dataset (2008)

http://www.unodc.org/

\section{OECD Aid Statistics}

ERS International Macroeconomic Data Set

Voeten and Merdzanovic (2008), Kilby (2009)

UN Commodity trade statistics database (COMTRADE, 2010)

www.eugenesoftware.org/ (Bennett and Stam 2010)

Russett, Oneal, and Cox (2000)

UNODC (2006)

Kaufmann, Kraay and Mastruzzi (2009)

International Country Risk Guide. PRS Group (2009)

Dreher et al. (2008)

http://globalization.kof.ethz.ch/

Freedom house (2009)

http://europa.eu/about-eu/membercountries/index_en.htm/ World Development Indicator 
Appendix C: Descriptive Statistics

\begin{tabular}{llllll}
\hline Variables & Observations & Mean & Std. Errors & Minimum & Maximum \\
\hline Prosecution & 918 & 3.80 & 1.17 & 1.00 & 5.00 \\
Protection & 918 & 2.92 & 1.06 & 1.00 & 5.00 \\
Prevention & 918 & 3.35 & 0.88 & 1.00 & 5.00 \\
Aggregate 3Ps & 918 & 10.07 & 3.00 & 3.00 & 15.00 \\
Tier-ranking & 918 & 1.86 & 1.00 & 1.00 & 3.00 \\
Control of Corruption & 918 & -0.10 & 1.00 & -1.63 & 2.58 \\
Democracy & 918 & 4.50 & 5.93 & -10.00 & 10.00 \\
Women legislators (\%) & 918 & 16.46 & 10.10 & 0.00 & 56.30 \\
Women’s economic rights & 918 & 1.28 & 0.73 & 0.00 & 3.00 \\
Intl. regime membership & 918 & 0.59 & 0.49 & 0.00 & 1.00 \\
(log) GDP pc & 918 & 7.94 & 1.65 & 4.50 & 11.37 \\
US aid (\% of GDP) & 918 & 0.75 & 2.32 & 0.00 & 44.56 \\
\hline
\end{tabular}

